\title{
THE APPLICATION OF PCR IN THE DETECTION OF MYCOTOXIGENIC FUNGI IN FOODS
}

\author{
Ursula Konietzny ${ }^{1}$; Ralf Greiner ${ }^{1,2 *}$ \\ ${ }^{1}$ Dettenheim, Germany. ${ }^{2}$ Federal Research Centre for Nutrition, Centre for Molecular Biology, Karlsruhe, Germany.
}

Submitted: November 26, 2003; Approved: December 08, 2003

\begin{abstract}
It is estimated that 25 to $50 \%$ of the crops harvested worldwide are contaminated with mycotoxins. Because of the toxic and carcinogenic potential of mycotoxins, there is an urgent need to develop detection methods that are rapid and highly specific. The highly advanced physico-chemical methods for the analysis of mycotoxins in use, have the disadvantage that highly sophisticated clean-up and/or derivatization procedures must be applied. An alternative could be the detection of the mycotoxigenic moulds themselves, especially as molecular techniques have been introduced recently as powerful tools for detecting and identifying fungi. PCR methods for the detection of aflatoxigenic Aspergilli, patulin-producing Penicillum and trichothecene- as well as fumonisin-producing Fusaria strains have been described. The usefulness of the PCR methods developed so far to monitor quality and safety in the food an feed industry was already demonstrated. Thus, PCR may be applied to the screening of agricultural commodities for the absence of mycotoxin producers prior to or even after processing. Negative results in this assay indicate that a sample should be virtually free of mycotoxins. Only the positive samples left must be analyzed for the presence of mycotoxins using physicochemical standard methods. This review does not only summarize the so far developed qualitative and quantitative PCR assays for the detection of mycotoxigenic fungi in agricultural commodities, foods and animal feeds, but describes also strategies to develop new specific PCR assays for such a detection.
\end{abstract}

Key words: aflatoxin, fumonisin, patulin, polymerase chain reaction, trichothecene.

\section{INTRODUCTION}

Nearly every food or feed commodity can be contaminated by fungal organisms and many of the food- and feed-borne filamentous fungi are capable of producing one or more mycotoxins, which are toxic metabolites of concern to both the health of humans and animals (48). While some mycotoxins are produced only by a limited number of species others may be produced by a relatively large range of species from several genera. It is estimated that 25 to $50 \%$ of the crops harvested worldwide are contaminated with mycotoxins. The percentage is highest in tropical regions where up to $80 \%$ of the crops are reported to contain significant amounts of mycotoxins. Besides crops, foods of animal origin can be contaminated with mycotoxins by carry-over from mycotoxin-containing animal feed. While over 300 mycotoxins have been identified, mostly these have been demonstrated under laboratory conditions and only a relatively small number of about 20 have so far been shown to occur naturally in foods and animal feeds at significant levels and frequency to be of safety concern (Table 1). Because of the toxic and carcinogenic potential of mycotoxins, there is an urgent need to develop detection methods that are rapid and highly specific. Because mycotoxins have diverse chemical structures (Fig. 1), it is not possible to develop one method to detect all relevant mycotoxins, even if some progress was achieved in the simultaneous detection of several mycotoxins $(11,54)$. The highly advanced physico-chemical methods for the analysis of mycotoxins in use, have above all the disadvantage that highly sophisticated clean-up and/or derivatization procedures must be applied (48). In addition, there are much simpler and faster immuno-chemical methods available $(48,57)$, which have in turn the disadvantage to follow the

*Corresponding author: Mailing Address. Federal Research Centre for Nutrition. Haid-und-Neu-Strasse 9. 76131 Karlsruhe, Germany. Tel.: (+49721) 6625-479. Fax: (+49721)6625-457. E-mail: ralf.greiner@bfe.uni-karlsruhe.de 
Table 1. Mycotoxins relevant to human health.

\begin{tabular}{lll}
\hline \multicolumn{1}{c}{ mycotoxin } & $\begin{array}{c}\text { generating } \\
\text { fungus }\end{array}$ & \multicolumn{1}{c}{ contaminated commodity } \\
\hline deoxynivalenol & Fusarium & cereals \\
nivalenol & Fusarium & cereals \\
T2 toxin & Fusarium & cereals \\
fumonisins & Fusarium & cereals, legumes, meats, eggs \\
zearalenone & Fusarium & cereals \\
alternariol & Alternaria & cereals, oilseeds \\
alternariol monomethyl ether & Alternaria & cereals \\
tenuazonic acid & Alternaria & cereals, oilseeds \\
patulin & Penicillium & fruits, vegetables, meats, eggs, dairy products \\
citrinin & Penicillium & cereals, fruits, meats, eggs \\
roquefortine & Penicillium & cereals, meats, eggs \\
penicillic acid & Penicillium & cereals \\
ochratoxin A & Penicillium & cereals, tree nuts, spices, dairy products, meats, eggs, fish, coffee \\
cyclopiazonic acid & Penicillium & tree nuts, fruits, dairy products, meats, eggs \\
compactin & Penicillium & tree nuts, fruits, vegetables, fish, dairy products \\
cyclopaldic acid & Penicillium & tree nuts, fruits, dairy products, meats, eggs \\
citreomycetin & Penicillium & fruits, vegetables, meats, eggs \\
aflatoxins & Aspergillus & cereals, peanuts, pistachio, tree nuts, figs, spices, meats, dairy products \\
\hline
\end{tabular}

concept of "one substance one assay". Therefore, detection of the mycotoxigenic moulds themselves could be an alternative.

At present, monitoring of agricultural commodities, foods and animal feeds for the presence of a fungal contamination includes cultivation and taxonomic identification at the morphological level (29). This approach is, however, very timeconsuming, labor-intensive and requires the expertise of mycologists and above all possesses the inherent possibility of misclassification, since morphological characters could be highly variable depending on the media and culture conditions. Therefore, more rapid and more objective methods for the identification of mycotoxigenic fungi in human foods and animal feeds are needed for evaluating the microbiological risks of a given product. Recently, secondary metabolite profiles (12), isoenzyme analysis (10) and molecular techniques (19) have been introduced as powerful tools for detecting and identifying fungi.

\section{NUCLEIC ACID-BASED TECHNIQUES}

Nucleic acids present in agricultural commodities, foods and animal feeds are characteristic for the various biological components in complex products. Analysis of specific nucleic acids in these products allows the determination of the presence or absence of certain ingredients or contaminants as well as the identification of specific characteristics of single components $(7,32,35)$. DNA-based detection systems for genetically modified foods $(17,21,22,24,25,31,53)$ and food-borne pathogens $(1,2,21,27,51,55)$, including mycotoxin-producing fungi $(6,8,9,18,42,47)$, have been developed recently. Furthermore, the detection of plant and animal species in the final food products has been shown to be feasible with DNA-based methods $(33,34)$. Because of its high sensitivity, its specificity and rapidity the polymerase chain reaction (PCR) is the method of choice for this purpose (Fig. 2). The PCR is an in vitro method to selectively amplify DNA sequences of defined length. This is done by 25 to 40 repetitive cycles of heat denaturation, primer annealing and enzymatic primer extension; thereby generating billions of copies of the DNA sequence in between the primer binding sites. Primers are short single-stranded DNA molecules, usually 18 to 35 bases in length, designed to bind selectively to the complementary sequences of the target DNA segment. During primer annealing one primer has to bind in forward and the other one in a defined distance in reverse orientation to the separated DNA. Therefore, designing PCR primers is a critical step in PCR analysis, since the PCR primers need to have the required sensitivity and specificity.

\section{DEVELOPMENT OF A PCR ASSAY}

A general strategy to develop a specific PCR assay to detect mycotoxigenic fungi is given in Fig. 3. For the detection of mycotoxin-producing fungi unique DNA sequences of the respective organisms have to be chosen as primer binding sites. It is concluded that genes involved in the mycotoxin biosynthetic pathway may form a perfect basis for an accurate, sensitive, and specific detection system for mycotoxigenic strains in agricultural commodities, foods and animal feeds, since those genes are supposed to be exclusively present in organisms 


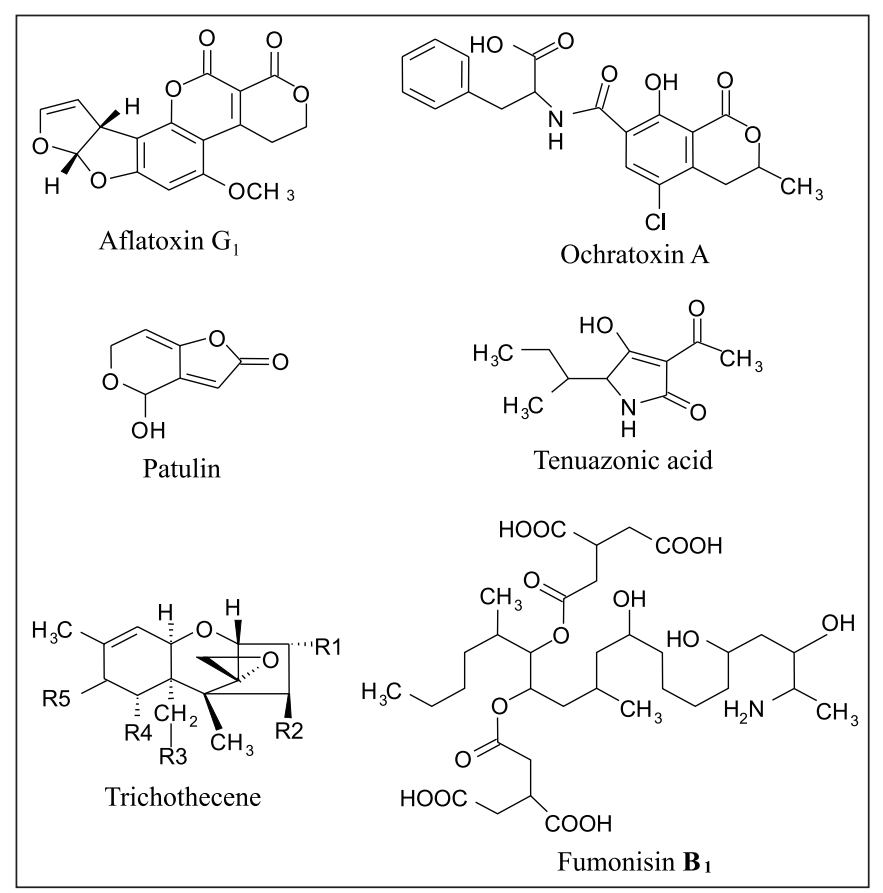

Figure 1. Structures of the major mycotoxins relevant for human health.

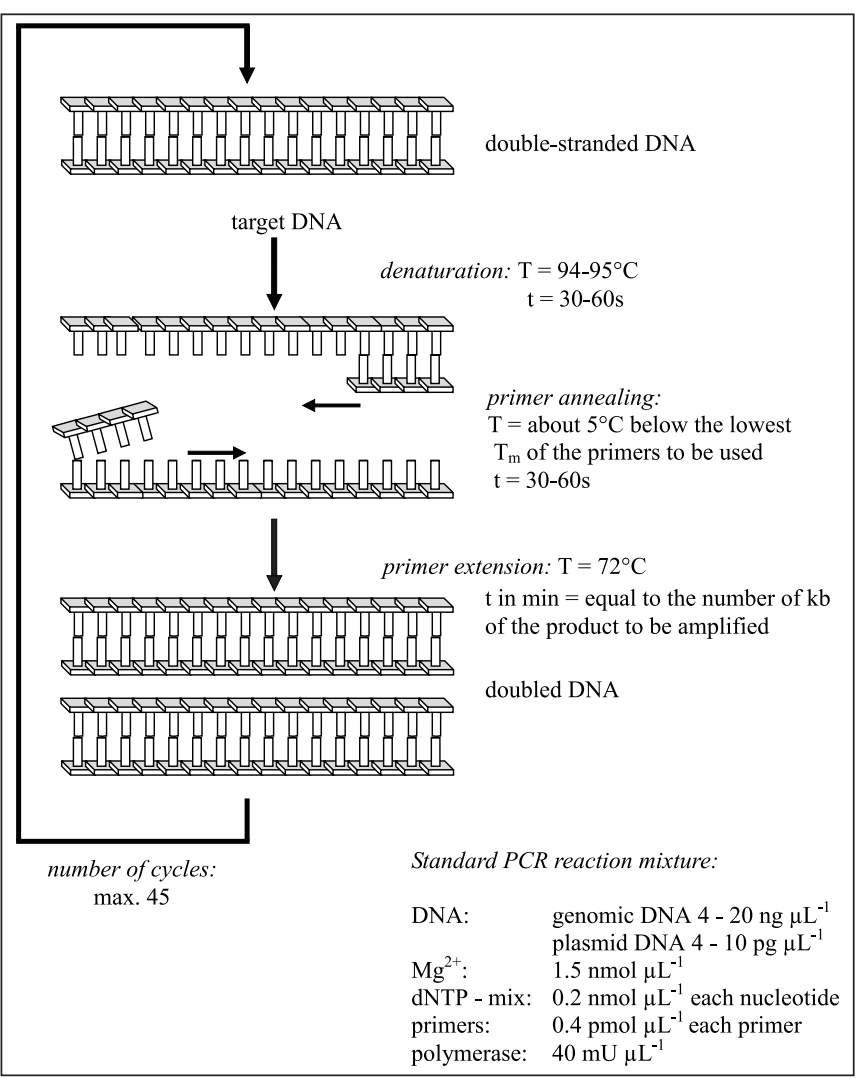

Figure 2. Polymerase Chain Reaction (PCR).

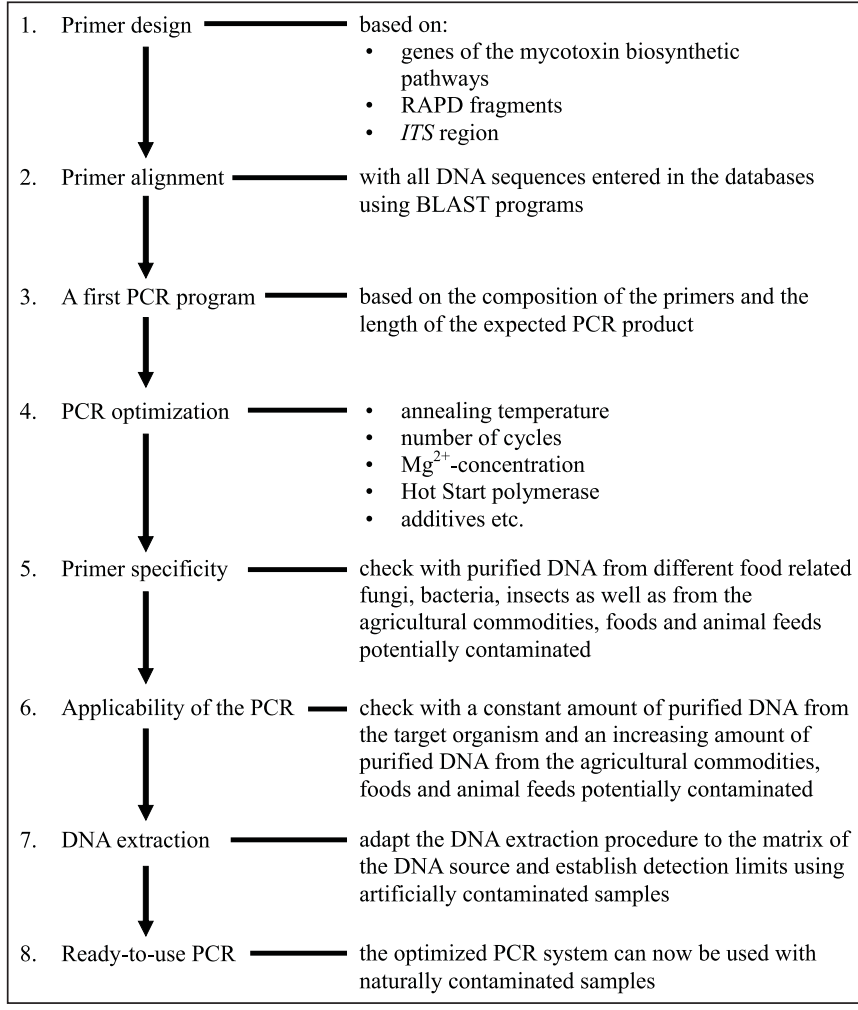

Figure 3. Strategy to develop a specific PCR assay to detect mycotoxigenic fungi.

potentially producing mycotoxins. In the recent years, progress was made to elucidate the biosynthetic pathways for aflatoxins (Fig. 4), patulin (Fig. 5) and trichothecens (Fig. 6) (43,49). Many genes involved in the biosynthesis of these mycotoxins have been identified and their DNA sequences have been published. In the meantime, PCR methods for the detection of aflatoxigenic Aspergilli based on the norsolorinic acid reductase encoding gene nor1, the versicolorin A dehydrogenase encoding gene ver1, the sterigmatocystin O-methyltransferase encoding gene $o m t \mathrm{~A}$, and the regulatory gene aflR have been described $(8,9,18,47)$. The trichodiene synthase encoding gene tri5, a yet non-identified protein encoding gene tri7, and the regulatory gene tri6 have been the targets for detecting trichotheceneproducing Fusaria $(6,42)$. The target sequence for the detection of patulin-producing Penicillum strains is within the isoepoxydon dehydrogenase encoding gene IDH (43).

If there is only limited or even no information available about genes involved in a certain mycotoxin biosynthetic pathway, specific primers can be designed, for example, by random amplified polymorphic DNA (RAPD) analysis or by analyzing the fungal ribosomal region. Instead of using two primers that are designed based on pre-existing knowledge of the target sequence, RAPDs are produced from single, with respect to sequence randomly chosen, oligonucleotide primers, typically 


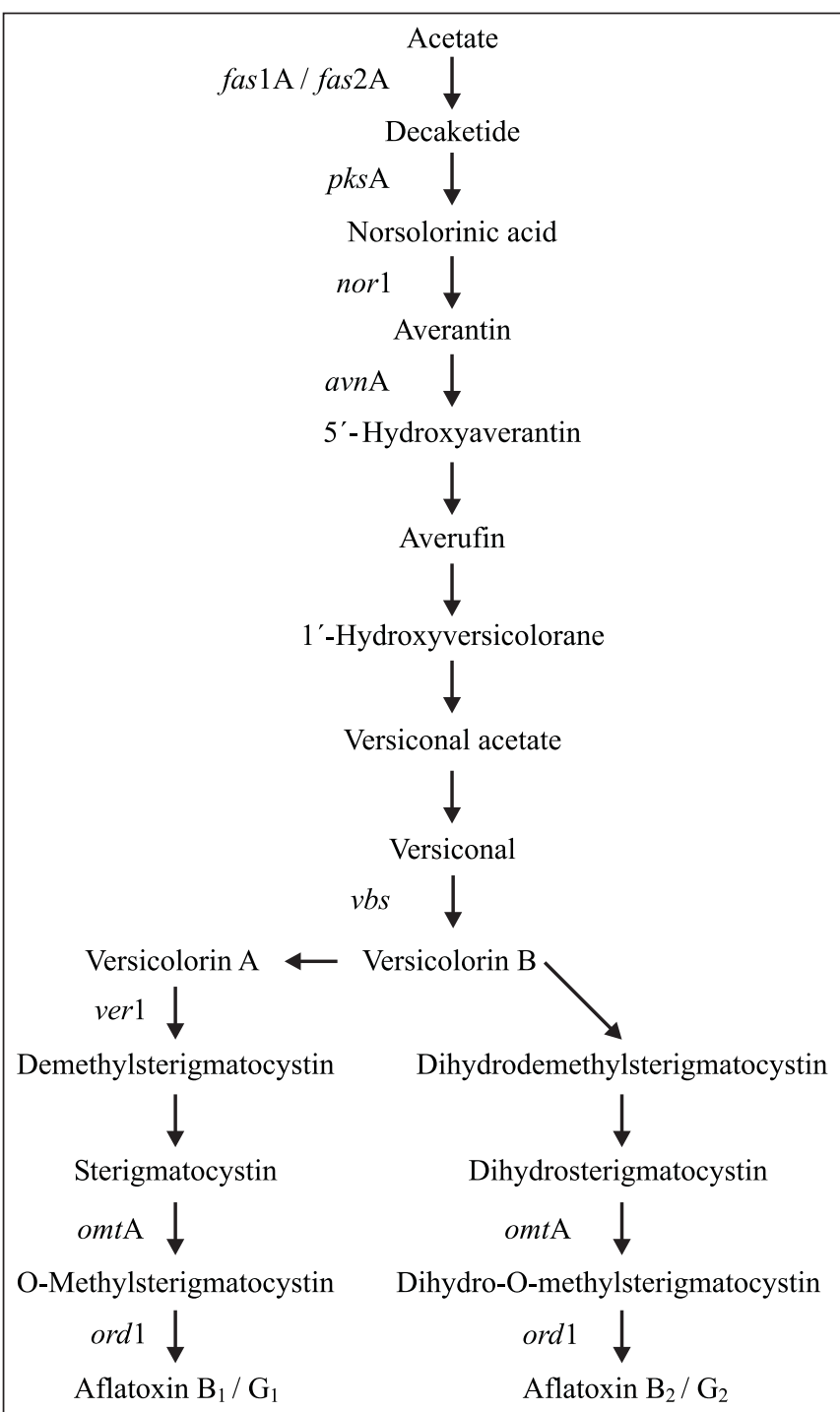

Figure 4. Biosynthetic pathway of aflatoxins.

(fas $1 \mathrm{~A} /$ fas $2 \mathrm{~A}$ : fatty acid synthase encoding gene; pks A: polyketide synthase encoding gene; nor 1 : norsolorinic acid reductase encoding gene; avnA: non-identified gene product; $v b s$ : versicolorin B synthase encoding gene; ver 1 : versicolorin A dehydrogenase encoding gene, omtA: sterigmatocystin Omethyltransferase encoding gene, ord 1 : non-identified gene product; aflR: regulatory gene)

10 bases long. The complexity of eukaryotic nuclear DNA is sufficiently high, that by chance these RAPD primers bind to the DNA in both forward and reverse orientations close enough to one another for PCR amplification. With some randomly chosen RAPD primers no sequences are amplified, with others, the same length products are generated from DNA of different genera, species or subspecies and with still others, patterns of

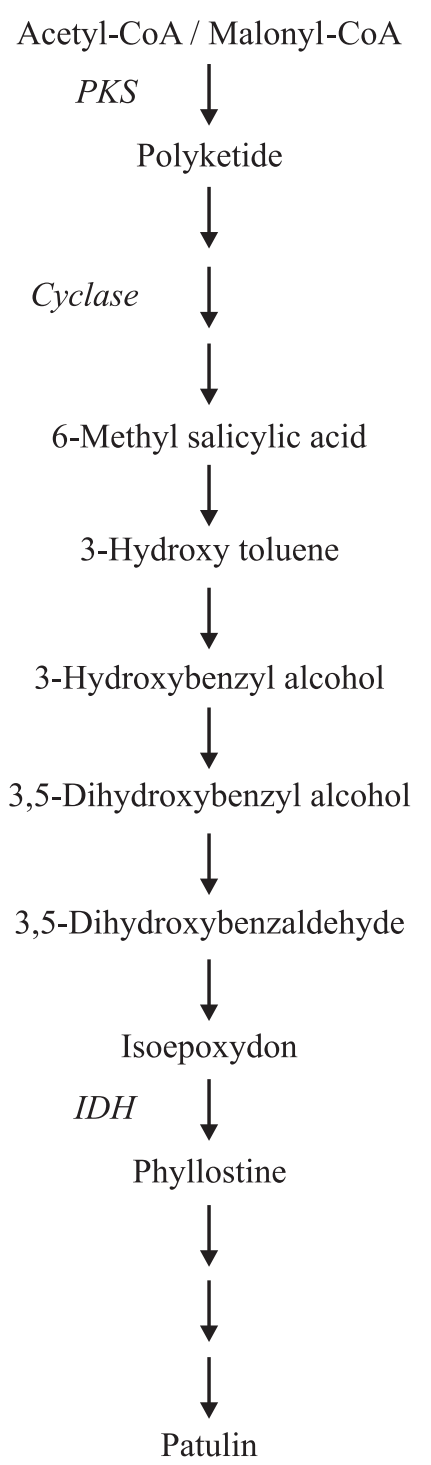

Figure 5. Biosynthetic pathway of patulin. (PKS: polyketide synthase encoding gene; $I D H$ : isoepoxydon dehydrogenase encoding gene)

bands are different on genus, species or subspecies level. RAPD fragments unique for the fungi to be detected are sequenced and based on these sequences it should be possible to design primers for the development of a specific PCR system. Möller et al. (37) used the UBC18 primer for RAPD analysis of a set of representative Fusarium isolates. The strong 600 bp fragment obtained seemed to be exclusively amplified from Fusarium moniliforme. The PCR fragment was cloned into a plasmid and sequenced. On the basis of the obtained DNA sequence a specific primer pair for Fusarium moniliforme was designed (Table 2). The same approach was used to design primer specific 


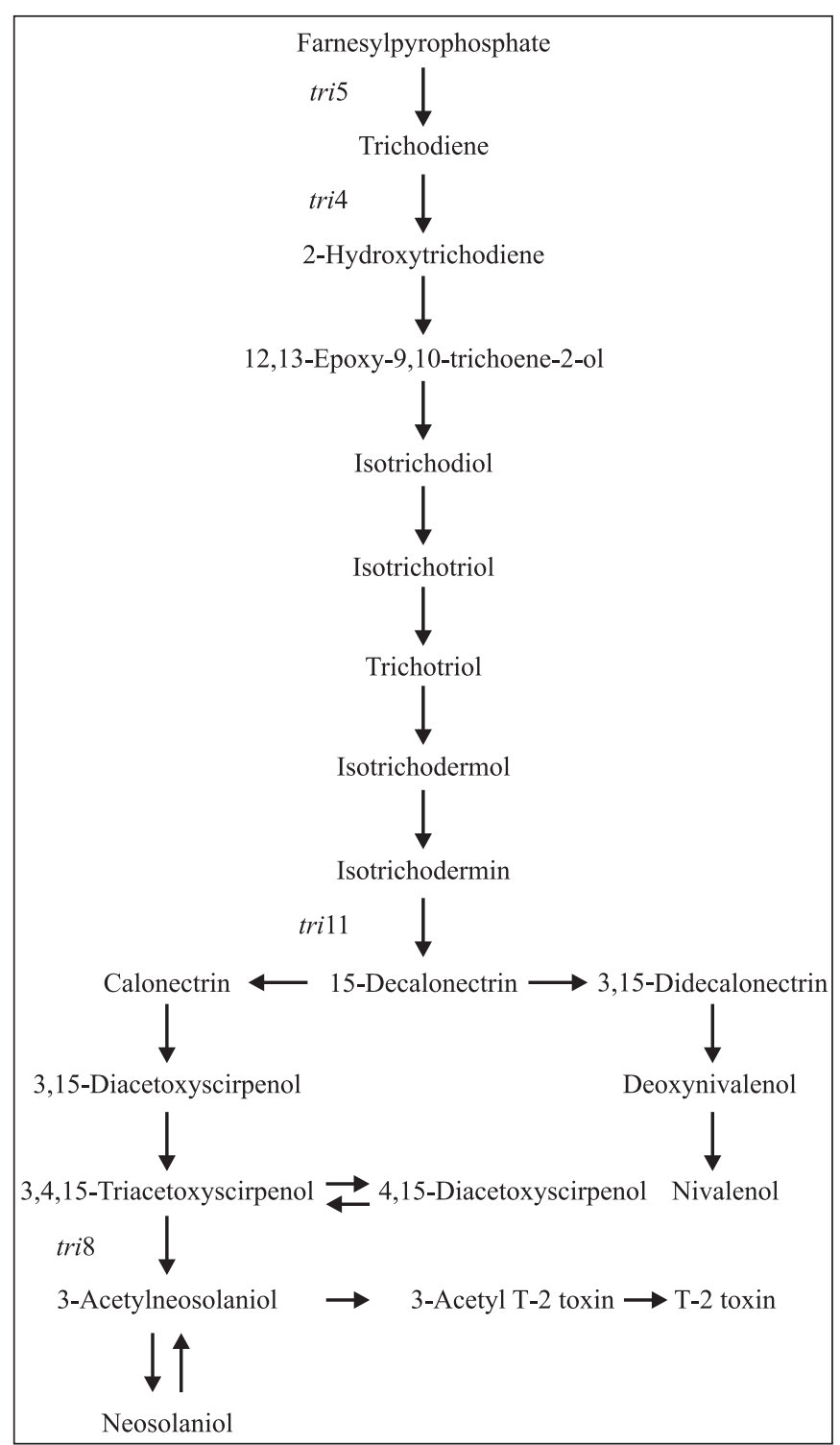

Figure 6. Biosynthetic pathway of trichothecenes.

(tri3: non-identified gene product; tri4: non-identified gene product; tri5: trichodiene synthase encoding gene; tri7: nonidentified gene product; tri8: non-identified gene product; tri6: regulatory gene; tri11: non-identified gene product)

for Fusarium subglutinans, Fusarium culmorum and Fusarium graminearum (Table 2) $(37,40)$.

The organization of the ribosomal genes is conserved in fungi. Eukaryotic fungal ribosomal genes are arranged in a tandem repeat and within the ribosomal DNA repeat, the two variable non-coding internal transcribed spacer regions (ITS regions) are nested between the highly conserved 5.8S nuclear small subunit ribosomal RNA and the two large subunit ribosomal RNA genes. The ribosomal region spanning ITS1,
$5.8 \mathrm{~S}$ and ITS 2 is often between 600 and $800 \mathrm{bp}$ long. The fungal ribosomal genes are highly conserved at the genus level or even higher, but the internal transcribed spacers ITS1 and ITS2 and the intergenic spacer IGS have evolved faster than the ribosomal genes and may therefore be more useful for the development of specific oligonucleotide primers, aimed at differentiating at the genus, species or subspecies level. Several studies have shown that the ITS regions are highly variable among and within different fungal species. In order to identify specific primer binding sites for a PCR to detect mycotoxinproducing fungi, either ITS1 or ITS2 or even both are amplified in several mycotoxin producers and non-producers by using primers binding to the conserved regions of the structural ribosomal RNA genes (40). The sequences of the obtained PCR products are compared in order to identify regions which may serve as target sites in a PCR to distinguish toxigenic from nontoxigenic fungi or to detect fungi at the genus or species level. Grimm and Geisen (23) used ITS1 sequences to develop a PCR assay for the detection of potential fumonisin-producing Fusarium species (Table 3). In addition, species-specific primers (36) as well as primers for genus level recognition (6) of Fusarium species were designed based on the DNA sequence variability found within the internal transcribed spacer regions of the ribosomal DNA (Table 2).

Before setting up a PCR system with the designed primers, the primer sequences should be aligned with all DNA sequences entered in the databases, such as the NCBI sequence database, using BLAST programs to reduce the likelihood of mispriming. Now a PCR assay with the chosen primer pair has to be established using DNA from the target organism isolated from a pure culture as a template. For any given primer pair, a first PCR program can be selected based on the composition of the primers and the length of the expected PCR product (Fig. 2). Sometimes this first PCR program results either in non-specific amplification, that is not only the expected but more PCR products are detected, or in a weak or even no PCR product at all. Then, there is a need to optimize the PCR. Since the aim of PCR is to amplify a specific DNA sequence without any nonspecific by-products, primer annealing needs to take place at a sufficiently high temperature to allow only the perfect DNADNA matches to occur in the reaction. Thus, the likelihood of non-specific amplification can be reduced by increasing the annealing temperature, whereas decreasing the annealing temperature is a way to improve the yield of the expected PCR product. Within limits, modification in the concentration of magnesium ions may improve the outcome of the PCR assay, and should be considered as a way to optimize PCR. Furthermore, Hot Start is a PCR refinement that suppresses mispriming artefacts and results in a more sensitive, consistent reaction with concomitantly higher yields. The easiest way to carry out a Hot Start is simply to withhold addition of the DNA polymerase until the reaction has reached the denaturation 
Table 2. Genus and species-specific primer systems for the detection of mycotoxigenic fungi.

\begin{tabular}{|c|c|c|c|c|c|}
\hline target species & & primer designation and sequence & $\begin{array}{l}\text { annealing } \\
\text { temp. }\left[{ }^{\circ} \mathrm{C}\right]\end{array}$ & $\begin{array}{c}\text { PCR product } \\
\text { size [bp] }\end{array}$ & reference \\
\hline \multirow[t]{2}{*}{ Fusarium species } & ItsF & 5'-AAC TCC CAA ACC CCT GTG AAC ATA-3' & 62 & 431 & (6) \\
\hline & ItsR & 5'-TTT AAC GGC GTG GCC GC-3' & & & \\
\hline \multirow[t]{2}{*}{ F. moniliforme } & $53-6 \mathrm{~F}$ & 5'-TTT ACG AGG CGG CGA TGG GT -3' & 65 & 561 & (37) \\
\hline & $53-6 \mathrm{R}$ & 5'-GGC CGT TTA CCT GGC TTC TT-3' & & & \\
\hline \multirow[t]{2}{*}{ F. subglutinans } & $61-2 \mathrm{~F}$ & 5'-GGC CAC TCA AGA GGC GAA AG -3' & 64 & 445 & (37) \\
\hline & $61-2 \mathrm{R}$ & 5'-GTC AGA CCA GAG CAA TGG GC-3' & & & \\
\hline \multirow[t]{4}{*}{ F. culmorum } & $\mathrm{Fc} 01 \mathrm{~F}$ & $5^{\prime}$-ATG GTG AAC TCG TCC TGG C-3' & 62 & 570 & (40) \\
\hline & Fc01R & $5^{\prime}$-CCC TTC TTA CGC CAA TCT CG -3' & & & \\
\hline & $175 \mathrm{~F}$ & $5^{\prime}$-TTT TAG TGG AAC TTC TGA GTA T -3' & 58 & 245 & (36) \\
\hline & $430 \mathrm{R}$ & 5'-AGT GCA GCA GGA CTG CAG C-3' & & & \\
\hline \multirow[t]{4}{*}{ F. graminearum } & Fg16NF & 5'-ACA GAT GAC AAG ATT CAG GCA CA -3' & 62 & 280 & (40) \\
\hline & Fg16NR & $5^{\prime}$-TTC TTT GAC ATC TGT TCA ACC CA-3' & & & \\
\hline & GaoA-V2 & $5^{\prime}$-AGG GAC AAT AAG TGC AGA-3' & 56 & 896 & (26) \\
\hline & Gao-R2 & 5'-ACT GTG CAC TGT CGC AAG TG -3' & & & \\
\hline \multirow[t]{2}{*}{ F. sambucinum } & FSF1 & 5'-ACA TAC CTT TAT GTT GCC TCG-3' & 58 & 315 & (36) \\
\hline & FSR1 & 5'-GGA GTG TCA GAC GAC AGC T-3' & & & \\
\hline \multirow[t]{2}{*}{ F. oxysporum } & FOF1 & $5^{\prime}$-ACA TAC CAC TTG TTG CCT CG-3' & 58 & 340 & (36) \\
\hline & FOR1 & 5'-CGC CAA TCA ATT TGA GGA ACG-3' & & & \\
\hline \multirow[t]{2}{*}{ F. equiseti } & FEF1 & 5'-CAT ACC TAT ACG TTG CCT CG-3' & 58 & 389 & (36) \\
\hline & FER1 & 5'-TTA CCA GTA ACG AGG TGT ATG-3' & & & \\
\hline \multirow[t]{2}{*}{ F. avenaceum } & FAF1 & 5'-AAC ATA CCT TAA TGT TGC CTC GG-3' & 58 & 314 & (36) \\
\hline & FAR1 & 5'-ATC CCC AAC ACC AAA CCC GAG-3' & & & \\
\hline
\end{tabular}

temperature. This is simple but laborious and a source of contamination, especially when large numbers of samples are analyzed. A better way is to use a modified thermostable DNA polymerase, a so called Hot Start polymerase, which is inactive at room temperature and requires thermal activation. In this case, the activation of the polymerase will occur through incubation of the enzyme for several minutes at $95^{\circ} \mathrm{C}$, that is during the first denaturation step. Last but not least, a variety of PCR additives and enhancing agents have been used to increase the yield, specificity and consistency of PCRs. Whilst these additives may have beneficial effects on some amplifications, it is impossible to predict which agents will be useful in a particular context and therefore they must be empirically tested for each combination of template and primers. The most popular additives used are glycerol, dimethyl sulfoxide (DMSO), formamide, betaine, tetramethylammonium chloride
(TMAC), bovine serum albumin (BSA) and non-ionic detergents such as Triton X-100, Tween 20 or NP-40.

\section{SPECIFICITY OF THE PCR}

After development of an optimized PCR system for the target mycotoxin-producing fungi, the specificity of the chosen primer pairs have to be demonstrated by testing for cross-reactivity against purified DNA from different food-related fungi, bacteria, insects as well as from the agricultural commodities, foods or animal feeds potentially contaminated. The importance to test the primers used for PCR for cross-reactivity was shown clearly by Möller et al. (37). They used a primer pair described by Murillo et al. (39) to exclusively amplify the DNA from Fusarium moniliforme without testing it for cross-reactivity with DNA from related species and it went clear that DNA from other genera 
yielded several fragments differing in size and intensity including the predicted amplicon size. Consequently, the PCR assay of Murillo et al. (39) is not specific for Fusarium moniliforme.

Two very extensive investigation to demonstrate the specificity of the chosen primer pairs can be found in the literature. Niessen and Vogel (42) developed a PCR-based assay to detect Fusarium species potentially producing trichothecenes using a pair of primers derived from the DNA sequence of the trichodiene synthase encoding gene tri5 (Table 3 ). The primer pair was tested for cross-reactivity with DNA isolated from a variety of strains representing 64 species and varieties of Fusarium as well as from other fungi, bacteria and cereals. Bluhm et al. (6) determined the specificity of their ITS primers to detect Fusarium (Table 2) with purified genomic DNA from 43 fungal species representing 14 genera, including 9 Aspergillus, 9 Fusarium, and 10 Penicillium species. It has been shown that the primers were highly specific for the genus Fusarium. All nine Fusarium species produced a PCR product of the expected size. In addition, it is of utmost importance to be able to detect the target fungal sequences in a high background of DNA from the agricultural commodity, food or animal feed, since high amounts of non-target DNA may act as a PCR inhibitor and the products to be analyzed may contain only a limited amount of fungi. Therefore, the applicability of a given PCR has to be studied with a constant amount of purified DNA from the target organism isolated from a pure culture with an increasing amount of purified DNA from the agricultural commodity, food or animal feed to be analyzed.

\section{PCR SYSTEMS FOR THE DETECTION OF MYCOTOXIGENIC FUNGI}

In the recent years, several detection systems for mycotoxigenic fungi have been developed. PCR methods for the detection of aflatoxigenic Aspergilli, patulin-producing Penicillium and trichothecene- as well as fumonisin-producing Fusaria strains have been described and PCR assays for the detection of ochratoxin-producing fungi are under development.

\section{TRICHOTHECENE-PRODUCING FUSARIUM SPECIES}

Niessen and Vogel (42) targeted the trichodiene synthase encoding gene tri5, which is involved in trichothecene biosynthesis in their group-specific PCR assay for the detection of trichothecene-producing Fusarium species. The tri5 gene is functionally situated at the very beginning of the trichothecene biosynthetic gene cluster (Fig. 6). The enzyme catalyzes the isomerization and cyclization of farnesyl pyrophosphate to yield trichodiene, the initial specific product in the biosynthetic pathway, leading to the diversity of trichothecene derivatives known. The sequences used for construction of the PCR primers Tox 5-1 and Tox 5-2 were taken from two highly conserved regions found in the tri5 gene showing a distance of $658 \mathrm{bp}$ which is the predicted length of the PCR product (Table 3). Optimization of the PCR cycling program and amplification buffer was performed using a small set of Fusarium species. PCR resulted in one single band of the predicted size using the optimized cycling protocol. From the 64 species and varieties of Fusarium tested in this study, 21 showed production of an appropriate fragment in the PCR employed. Amplification of a DNA fragment occurred in all species described as producers of trichothecene in the literature reviewed. A missing PCR fragment for some of the species in this study also supports findings by others, which state no production of trichothecene for some species formerly described as producers. No information on the toxigenic potential of Fusarium lunulosporum and Fusarium robustum, which were tri5 positive, could be found in the literature. Their capability to produce trichothecens remains to be studied. Thus, it was demonstrated that the primer pair designed by Niessen and Vogel (42) can be used for a group-specific detection of trichothecene producing Fusarium species.

\section{FUMONISIN-PRODUCING FUSARIUM SPECIES}

A PCR-ELISA for the detection of potentially fumonisinproducing Fusarium species has been developed by Grimm and Geisen (23), using the ribosomal ITS1 sequence as a target (Table 3). All other ubiquitously occurring food-borne fungi tested showed negative results with this PCR. The fumonisins are a group of mycotoxins produced primarily by Fusarium species such as Fusarium moniliforme, Fusarium proliferatum, Fusarium nygamai and Fusarium napiforme. Performing the PCR-ELISA increased the specificity of the PCR assay compared to the PCR itself; chromosomal DNA which give false positive results in the PCR were negative after being subjected to PCRELISA. All potential fumonisin-producing species gave a positive reaction in the PCR-ELISA and all other species tested were negative. From the data presented in that study, however, the possibility that the PCR-ELISA may cross-react with strains of non-fumonisin producing Fusarium species cannot be ruled out. Because of the high variability of the ITS regions among and within fungal species, it seems not to be very likely to be able to identify characteristic sequences for the detection of mycotoxigenic fungi within the ITS regions. Therefore, the ITS regions may not be the best choice for developing a PCR assay to distinguish toxin from non-toxin producers.

\section{TRICHOTHECENE-AND FUMONISIN-PRODUCING FUSARIUM SPECIES}

Bluhm et al. (6) developed a single PCR assay combining the detection of the Fusarium genus with the group-specific 
detection of both trichothecene-producing and fumonisinproducing Fusarium species. Thus, three primer sets were used in this multiplex PCR assay. Primers for genus-level recognition of Fusarium species were designed from the ITS regions of ribosomal DNA of several Fusarium species (Table 2) and the group-specific primer sets were designed from the tri6 gene involved in trichothecene biosynthesis and the fum 5 gene involved in fumonisin biosynthesis (Table 3). Amplification with the ITS primers resulted in a PCR product with all Fusarium species tested, but did not yield PCR products with any of the non-Fusarium species. The three trichothecene-producing Fusarium species tested, Fusarium culmorum, Fusarium graminearum, and Fusarium sporotrichioides, all scored positive for the expected product from the tri6 primer set and none of the other species tested yielded PCR products. The fum 5 primer set was also shown to be group-specific for fumonisin-producing Fusarium species. Only with Fusarium verticillioides and Fusarium proliferatum an amplification product of the predicted size was generated.

\section{PATULIN-PRODUCING PENICILLIUM SPECIES}

A detection system for patulin-producing fungi based on the isoepoxydon dehydrogenase $(I D H)$ gene was described by Paterson et al. (43). As expected, all patulin-producing fungi tested showed a PCR product, indicating the presence of the IDH gene of the patulin biosynthetic pathway (Fig. 5). Unfortunately, some fungi, which do not produce patulin generated a PCR product in the IDH PCR, too. Similar problems to distinguish mycotoxin-producers from non-producers by PCR based on one single gene was also observed in the detection of aflatoxigenic fungi.

\section{AFLATOXIN-PRODUCING ASPERGILLUS SSPECIES}

The use of multiple primer pairs, coding for different stages in mycotoxin biosynthesis, should strengthen the validity of a particular strain's identification as mycotoxigenic. Several multiplex PCR systems for aflatoxin-producing fungi were developed recently $(8,9,18,47)$. Aflatoxins are produced mainly by Aspergillus flavus and Aspergillus parasiticus. Shapira et al. (47) described a group-specific assay for the detection for aflatoxin-producing Aspergillus species based on the ver 1 , omt $\mathrm{A}$, and aflR genes (Table 3), which are involved in aflatoxin biosynthesis (Fig. 4), whereas the PCR system described by Geisen (18) targeted the nor 1 , ver 1 and omtA genes (Table 3). In both systems all analyzed aflatoxigenic Aspergillus flavus and Aspergillus parasiticus strains gave the expected triplet pattern, indicating the presence of all three targeted biosynthetic genes in these strains. Furthermore, the triplet pattern resulting from aflatoxigenic Aspergillus flavus strains was identical to that of
Aspergillus parasiticus strains, indicating high sequence homology between the two species. According to the literature, most of the isolated Aspergillus parasiticus strains are capable of producing aflatoxin and should be positive in the multiplex PCR, but only 40 to $50 \%$ of the isolated Aspergillus flavus strains produce aflatoxin. This inability to produce aflatoxin might be due to deletions or other mutations in the aflatoxin biosynthetic genes. The three non-toxigenic Aspergillus flavus strains tested by Geisen (18) showed varying results in the PCR assay. Aspergillus flavus BFE310 was negative in all three PCR assays, indicating a deletion of the whole or most of the aflatoxin biosynthetic gene cluster. Aspergillus flavus BFE311 was negative with the primer pair specific for the omt A gene, indicating a deletion in that gene, whereas Aspergillus flavus BFE301 showed the complete triplet pattern, indicating another type of mutation, perhaps in a regulatory gene. Since all genes for aflatoxin production belong to the same gene cluster, it is likely that the deletion of these genes would be the result of a single event. Therefore, it is assumed that in double deletion strains all genes between this two deletion are lost.

The analyzed Aspergillus versicolor strain did also possess the same triplet pattern (18), indicating that this strain also contains aflatoxin biosynthetic genes homologous to those of Aspergillus flavus and Aspergillus parasiticus, respectively. Aspergillus versicolor is capable of producing a set of different sterigmatocystins, depending on different ligands or the saturation status of the molecule. Therefore, this PCR result is not surprising, as sterigmatocystin is a direct precursor of aflatoxin and the same enzymes should be needed for its biosynthesis (Fig. 4). Two further species, Aspergillus oryzae and Aspergillus sojae, which are used as koji moulds for the production of oriental fermented foods, such as sake, miso, soy sauce are closely related to Aspergillus flavus and Aspergillus parasiticus. Both species do not produce aflatoxin, but the strains studied by Geisen (18) apparently carry sequence homologous to the ver 1 and omt A gene, but the primer set specific for the nor 1 gene gave no signal indicating missing primer binding sites due to sequence variation in or deletion of that gene. The nor 1 gene encodes one of the first enzymes within the aflatoxin biosynthetic pathway (Fig. 4). A deletion of this gene or an inactivation due to sequence variation can block the pathway very early and might be an explanation for the inability of the studied strains to produce aflatoxin. In a further study it was shown, that some Aspergillus oryzae and Aspergillus sojae strains scored positive for all three PCR products (8), but the aflatoxin biosynthetic gene related sequences are pseudo-genes which are not expressed in this strains. Most other food related strains studied showed negative results with all three primer sets (18). The exception was Penicillium roqueforti which showed a duplex PCR pattern. The nor 1 PCR signal had the same length as for the aflatoxigenic Aspergilli, whereas the ver 1 PCR product was slightly larger 
than the corresponding amplification product of the aflatoxigenic Aspergilli. Penicillium roqueforti is capable of producing several polyketide secondary metabolites like patulin, penicillinic acid and mycophenolic acid, but if Penicillium roqueforti contains genes similar to the aflatoxin biosynthetic genes of Aspergillus parasiticus has to be shown in further studies. Thus, the described multiplex PCRs with three sets of primers were capable of distinguishing Aspergillus flavus and Aspergillus parasiticus from other food-borne fungi, but not always aflatoxin-producing from non-producing strains of the same species. Therefore, quadruplex PCRs were developed to distinguish aflatoxin-producing from non-producing strains of the Aspergillus flavus group. Two quadruplex systems were set up by combining the previously described PCR systems with three primer sets. Therefore, both used the omtA, ver1, nor 1 and aflR genes as targets. The PCR system developed by Criseo et al. (9) uses the PCR primers described by Geisen (18) for the omtA, ver 1 and nor 1 genes and those described by Shapira et al. (47) for the aflR gene, whereas the PCR system developed by Chen et al. (8) uses the PCR primers described by Geisen (18) for the ver 1 and nor 1 genes and those described by Shapira et al. (47) for the omtA and aflR genes (Table 3). In the study of Chen et al. (8) 19 strains of the Aspergillus flavus group, including Aspergillus flavus, Aspergillus parasiticus, Aspergillus oryzae, Aspergillus sojae, and one Aspergillus niger, were subjected to PCR testing. Fifteen strains were shown to possess the four target DNA fragments. With regard to aflatoxigenicity, all seven aflatoxigenic strains possessed the four DNA fragments, and five strains bearing less than the four DNA fragments did not produce aflatoxin. On the other hand, all Aspergillus parasiticus strains possessed the four DNA fragments, but two of them were non-aflatoxigenic. Similarly, all Aspergillus oryzae and Aspergillus sojae strains were nonaflatoxigenic, but three of them possessed all four of the DNA fragments. The quadruplex PCR developed by Criseo et al. (9) gave comparable results. All aflatoxigenic strains showed a quadruplet pattern, indicating the presence of all four genes of the aflatoxin biosynthetic pathway. Non-aflatoxigenic strains gave varying results with one, two, three or four banding patterns. Thus, the presence of a quadruplet pattern for some non-aflatoxigenic strains of the Aspergillus flavus group indicates that this is not a sufficient marker for the differentiation of aflatoxigenic from non-aflatoxigenic strains.

\section{OTHER APPLICATIONS}

Furthermore it was shown, that it is possible by PCR to distinguish high from low deoxynivalenol-producing or deoxynivalenol-producing from nivalenol-producing Fusarium strains. 17 Fusarium culmorum strains studied by Bakan et al. (5) produced more than $1 \mathrm{ppm}$ deoxynivalenol (DON) and were considered high-deoxynivalenol-producing strains, whereas 13
Fusarium culmorum strains produced less than $0.07 \mathrm{ppm}$ of DON and were considered low-deoxynivalenol-producing strains. According to the tri5-tri6 sequences, PCR primers were designed in order to distinguish high-producing from the lowproducing Fusarium culmorum strains (Table 3). Amplification with N1-2 and N1-2R yielded a 200 bp fragment for the highproducing strains, whereas no amplification was observed for the low-producing strains. Conversely, with the 4056 and 3551 primers, amplification yielded a $650 \mathrm{bp}$ fragment for the lowproducing strains, whereas no amplification was observed for the high-producing strains. A duplex PCR with both primer sets was also conducted, which resulted in differentiation of the high-producing from the low-producing Fusarium culmorum strains in one single multiplex PCR. Lee et al. (28) cloned and sequenced the gene cluster for trichothecene biosynthesis from two Fusarium graminearum strains, $\mathrm{H}-11$ is a DON producer isolated from maize, and 88-1 is a nivalenol (NIV) producer from barley. Between H-11 and 88-1 all of the tri homologues except tri7 were conserved, with identities ranging from 88 to $98 \%$ and 82 to $99 \%$ at the nucleotide and amino acid levels, respectively. The tri 7 sequences were only $80 \%$ identical at the nucleotide level. The $t r i 7$ genes were aligned and it was found that the tri7 open reading frame of $\mathrm{H}-11$ carried several mutations and an insertion containing 10 copies of an 11-bp tandem repeat. The tri7 gene from 88-1 carried neither the repeat nor the mutations. A primer pair from the tri 7 gene was designed to generate a PCR product spanning this tri7 insertion (Table 3). 100 Fusarium graminearum strains were assayed using this primer pair. Amplification yielded PCR products ranging from 173 to 327 bp, depending on the number of 11-bp repeats within each sequence, from DON-producing Fusarium graminearum strains, whereas the PCR-products from NIV-producing strains were with $161 \mathrm{bp}$ identical in size due to a lack of the repeat. The inserted repeats in the tri 7 sequences varied from 2 to 16 copies for the 50 DON-producing isolates studied.

\section{PCR ASSAY WITH NATURAL SAMPLES}

After optimization of the PCR parameters with genomic DNA isolated from the pure target organisms, this optimized PCR can be used with DNA isolated from the products potentially contaminated. Such a PCR analysis includes isolation of DNA from the sample to be analyzed, amplification of the target sequences by PCR, separation of the amplification products by agarose gel electrophoresis and estimation of their fragment sizes by comparison with a DNA length marker after staining with ethidium bromide.

Quality and yield of the isolated DNA are two critical factors in DNA preparations for PCR analysis. The term DNA quality is related to the suitability of the extracted DNA for PCR. Fat, polysaccharides, polyphenols and other secondary compounds are reported to pose a major problem in PCR analysis, since these 
Table 3. Group-specific primer systems for the detection of mycotoxigenic fungi.

\begin{tabular}{|c|c|c|c|c|c|c|}
\hline $\begin{array}{l}\text { mycotoxin } \\
\text { produced }\end{array}$ & $\begin{array}{c}\text { target } \\
\text { gene }\end{array}$ & & primer designation and sequence & $\begin{array}{l}\text { annealing } \\
\text { temp. }\left[{ }^{\circ} \mathrm{C}\right]\end{array}$ & $\begin{array}{l}\text { PCR product } \\
\text { size }[\mathrm{bp}]\end{array}$ & reference \\
\hline \multirow[t]{4}{*}{ trichothecene } & tri5 & $\begin{array}{l}\text { Tr5F } \\
\operatorname{Tr} 5 \mathrm{R}\end{array}$ & $\begin{array}{l}5^{\prime} \text {-AGC GAC TAC AGG CTT CCC TC -3' } \\
5^{\prime} \text {-AAA CCA TCC AGT TCT CCA TCT G-3' }\end{array}$ & 60 & 544 & (14) \\
\hline & tri5 & $\begin{array}{l}\text { Tox5-1 } \\
\text { Tox5-2 }\end{array}$ & $\begin{array}{l}5^{\prime} \text {-GCT GCT CAT CAC TTT GCT CAG -3' } \\
5^{\prime} \text {-CTG ATC TGG TCA CGC TCA TC }-3^{\prime}{ }^{\prime}\end{array}$ & 68 & 658 & (42) \\
\hline & tri5 & $\begin{array}{l}\text { HATri/F } \\
\text { HATri/R }\end{array}$ & $\begin{array}{l}5^{\prime} \text {-CAG ATG GAG AAC TGG ATG GT-3' } \\
5^{\prime} \text {-GCA CAA GTG CCA CGT GAC -3' }\end{array}$ & 62 & 260 & (15) \\
\hline & tri6 & $\begin{array}{l}\text { Tri6F } \\
\text { Tri6R }\end{array}$ & $\begin{array}{l}5^{\prime} \text {-CTC TTT GAT CGT GTT GCG TC-3' } \\
5^{\prime} \text {-CTT GTG TAT CCG CCT ATA GTG ATC }-3^{\prime}\end{array}$ & 62 & 596 & (6) \\
\hline high DON & tri5-tri6 & $\begin{array}{l}\text { N1-2 } \\
\text { N1-2R }\end{array}$ & $\begin{array}{l}5^{\prime} \text {-CTT GTT AAG CTA AGC GTT TT }-3^{\prime} \\
5^{\prime} \text {-AAC CCC TTT CCT ATG TGT TA }-3^{\prime}\end{array}$ & 55 & 200 & (5) \\
\hline low DON & tri5-tri6 & $\begin{array}{l}4056 \\
3551\end{array}$ & $\begin{array}{l}5^{\prime} \text {-ATC CCT CAA AAA CTG CCG CT -3' } \\
5^{\prime} \text {-ACT TTC CCA CCG AGT ATT TC }-3^{\prime}\end{array}$ & 55 & 650 & (5) \\
\hline DON & tri7 & $\begin{array}{l}\text { GzTri7/f1 } \\
\text { GzTri7/r1 }\end{array}$ & $\begin{array}{l}5^{\prime} \text {-GGC TTT ACG ACT CCT CAA CAA TGG-3' } \\
5^{\prime} \text {-AGA GCC CTG CGA AAG (C/T)AC TGG TGC -3' }\end{array}$ & 60 & $\begin{array}{c}161+a * 11 \\
(a=2,3 \ldots 16)\end{array}$ & (28) \\
\hline NIV & tri7 & $\begin{array}{l}\text { GzTri7/f1 } \\
\text { GzTri7/r1 }\end{array}$ & $\begin{array}{l}5^{\prime} \text {-GGC TTT ACG ACT CCT CAA CAA TGG-3' } \\
5^{\prime} \text {-AGA GCC CTG CGA AAG (C/T)AC TGG TGC-3' }\end{array}$ & 60 & 161 & (28) \\
\hline \multirow[t]{2}{*}{ fumonisin } & $I T S 1$ & $\begin{array}{l}\text { Int1 } \\
\text { Int2 }\end{array}$ & $\begin{array}{l}\text { 5'-CCG AGT TTA CAA CTC CCA AA-3' } \\
5^{\prime} \text {-ACA GAG TTT AGG GGT CCT CT-3' }\end{array}$ & 65 & 108 & (23) \\
\hline & fum 5 & $\begin{array}{l}\text { Fum5F } \\
\text { Fum5R }\end{array}$ & $\begin{array}{l}5^{\prime} \text {-GTC GAG TTG TTG ACC ACT GCG-3' } \\
5^{\prime} \text {-CGT ATC GTC AGC ATG ATG TAG C -3' }\end{array}$ & 62 & 845 & (6) \\
\hline \multirow[t]{9}{*}{ aflatoxin } & af $l \mathrm{R}$ & $\begin{array}{l}\text { aflR660 } \\
\text { aflR1249 }\end{array}$ & $\begin{array}{l}5^{\prime} \text {-CGC GCT CCC AGT CCC CTT CAT T-3' } \\
5^{\prime} \text {-CTT GTT CCC CGA GAT GAC CA-3' }\end{array}$ & 59 & 630 & (49) \\
\hline & af $l \mathrm{R}$ & $\begin{array}{l}\text { APA }-450 \\
\text { APA }-1482\end{array}$ & $\begin{array}{l}5^{\prime} \text {-TAT CTC CCC CCG GGC ATC TCC CGG-3' } \\
5^{\prime} \text {-CCG TCA GAC AGC CAC TGG ACA CGG-3' }\end{array}$ & 65 & 1032 & (46) \\
\hline & $\operatorname{ord} 1$ & $\begin{array}{l}\operatorname{ord} 1501 \\
\text { ord2226 }\end{array}$ & $\begin{array}{l}5^{\prime} \text {-TTA AGG CAG CGG AAT ACA AG-3' } \\
5^{\prime} \text {-GAC GCC CAA AGC CGA ACA CAA A-3' }\end{array}$ & 58 & 719 & (49) \\
\hline & nor 1 & $\begin{array}{l}\text { nortaq-1 } \\
\text { nortaq-2 }\end{array}$ & $\begin{array}{l}\text { 5'-GTC CAA GCA ACA GGC CAA GT-3' } \\
\text { 5'-TCG TGC ATG TTG GTG ATG GT-3' }^{\prime} \text {-' }\end{array}$ & 55 & 66 & $(4,30)$ \\
\hline & nor 1 & $\begin{array}{l}\text { nor1 } \\
\text { nor2 }\end{array}$ & $\begin{array}{l}5^{\prime} \text {-ACC GCT ACG CCG GCA CTC TCG GCA C -3' } \\
5^{\prime} \text {-GTT GGC CGC CAG CTT CGA CAC TCC G-3' }\end{array}$ & 65 & 400 & (18) \\
\hline & ver 1 & $\begin{array}{l}\text { ver1 } \\
\text { ver2 }\end{array}$ & $\begin{array}{l}5^{\prime} \text {-GCC GCA GGC CGC GGA GAA AGT GGT-3' } \\
5^{\prime} \text {-GGG GAT ATA CTC CCG CGA CAC AGC C - } 3^{\prime}\end{array}$ & 65 & 537 & (18) \\
\hline & ver 1 & $\begin{array}{l}\text { VER-496 } \\
\text { VER-1391 }\end{array}$ & $\begin{array}{l}5^{\prime} \text {-ATG TCG GAT AAT CAC CGT TTA GAT GGC -3' } \\
5^{\prime} \text {-CGA AAA GCG CCA CCA TCC ACC CCA ATG - } 3^{\prime}\end{array}$ & 65 & 895 & (46) \\
\hline & omt A & $\begin{array}{l}\text { omt1 } \\
\text { omt2 }\end{array}$ & $\begin{array}{l}5^{\prime} \text {-GTG GAC GGA CCT AGT CCG ACA TCA C-3' } \\
5^{\prime} \text {-GTC GGC GCC ACG CAC TGG GTT GGG G-3' }\end{array}$ & 65 & 797 & (18) \\
\hline & omt A & $\begin{array}{l}\text { OMT-208 } \\
\text { OMT-1232 }\end{array}$ & $\begin{array}{l}5^{\prime} \text {-GGC CCG GTT CCT TGG CTC CTA AGC -3' } \\
5^{\prime} \text {-CGC CCC AGT GAG ACC CTT CCT CG -3' }\end{array}$ & 65 & 1024 & (46) \\
\hline patulin & $I D H$ & $\begin{array}{l}\text { IDH-1 } \\
\text { IDH-2 }\end{array}$ & $\begin{array}{l}5^{\prime} \text {-CAA TGT GTC GTA CTG TGC CC-3' } \\
5^{\prime} \text {-ACC TTC AGT CGC TGT TCC TC - } 3^{\prime}\end{array}$ & 52 & 600 & (43) \\
\hline
\end{tabular}


compounds can irreversibly interact with proteins and nucleic acids and may therefore act as PCR inhibitors $(13,44)$. Depending on the quality of the DNA template and the primer systems used, the detection limits of the PCR with DNA isolated from pure fungal cultures on agarose gels stained with ethidium bromide were reported to be 1 to $10 \mathrm{pg}$ for multicopy genes (6) and 5 to $1000 \mathrm{pg}$ for single copy genes $(20,37,40)$, the latter corresponds to 100 to 20,000 fungal genome equivalents. Detection limits in foods were determined to be 10 to 100 -fold higher. Furthermore it was reported, that PCR even fails with food samples due to the presence of PCR inhibitors. Therefore it has to be shown, that a developed PCR system is still working with DNA extracted from complex food matrices. Shapira et al. (47) failed to detect aflatoxigenic fungi on maize even at the highest inoculum levels of $10^{6}$ spores per gram of maize by direct extraction of the DNA from the maize samples. By including an $12 \mathrm{~h}$ enrichment step, this problem could be overcome, but at the expense of the time needed for detection. Since enrichment steps result in the dilution of inhibitors, in an increased number of target cells and in an increased ratio of DNA derived from viable to DNA derived from dead cells, an improvement of the sensitivity of the detection system as well as a detection of only viable cells is achieved. The detection of only viable cells is of utmost importance in the detection of pathogenic microorganisms such as Salmonella or Listeria, because only viable cells have the potential to be toxigenic. For the evaluation of a potential contamination with mycotoxins however, it is an advantage to be able to detect a current as well as a former contamination with mycotoxigenic fungi. Because of their high stability, a given mycotoxin may persist in a critical concentration in a product even when the generating fungus is no longer present.

\section{DNA ISOLATION}

The amount and quality of the extracted DNA depends largely on the combination of sample matrix and extraction method applied. Therefore, a unique DNA isolation procedure for all the different products which have to be analyzed does not exist. To adapt the extraction procedure to the matrix of the DNA source and to establish the detection limits of the studied systems artificially contaminated samples have to be used. The identification of products as naturally contaminated with mycotoxigenic fungi could then be performed by using the optimized PCR assay, that is DNA isolation and the PCR itself. In principle, two different DNA isolation protocols with plenty of variations are used for DNA extraction from complex food matrices. The classical protocol for DNA isolation is based on an incubation of the samples in the presence of a detergent such as cetyltrimethylammonium bromide (CTAB) or sodium dodecylsulfate (SDS) and a treatment with organic solvents such as chloroform and phenol, respectively, followed by precipitation of DNA with isopropanol or ethanol (58). The second protocol is based on commercially available DNA- binding resins as ready to use kits. In general, the classical detergent-based methods result in higher DNA yields but poorer DNA quality compared to the DNA-binding resins and the extraction is more time-consuming $(21,58)$.

The yield and purity of the extracted DNA could be improved by adapting the extraction procedure to the matrix of the DNA source and the results presented in the literature demonstrate the functionality of the developed PCR assays to detect mycotoxigenic moulds without an enrichment step by isolation of DNA directly from agricultural commodities, foods or animal feeds, such as maize (6), wheat (26), peanuts (8), and figs (16). In general, the sample material was frozen in liquid nitrogen, ground in a mortar and re-suspended in a lysis buffer. An improvement of the sensitivity of the PCR assays has been shown by exclusion of inhibitory compounds from natural samples. One approach is to increase the ratio of fungal to sample tissue by using only the surface area of the sample tissue for DNA extraction (16). The other approach is to enhance fungal cell wall disruption prior to DNA extraction. This was achieved by thoroughly mixing the sample material with alumina in a lysis buffer $(4,16,20)$. As with the liquid nitrogen method, in some PCR assays additional bands appeared and the specific PCR products were rather weak $(16,20)$. These artefacts might be due to impurities from the sample tissue and could influence the interpretation of the results. The occurrence of artificial bands was greatly reduced with template DNA isolated by the ultrasonic method (38), whereby the samples were sonicated in a lysis buffer for 1 minute at maximum amplitude. Due to the rapidity and the possibility to handle multiple samples, the ultrasonic approach is also suitable for routine analysis. For purification of the extracted DNA the DNeasy Plant Mini kit from Qiagen has been widely used $(8,20,26,38,45)$.

\section{CONTROL REACTIONS}

Once the primers are designed and the conditions for a robust assay are optimized, PCR is a very sensitive, rapid, and relatively easy to handle assay for the detection of mycotoxigenic fungi in agricultural commodities, foods and animal feeds. The total detection time, that is the period of time from when the samples were taken until the PCR products were visualized, is approximately $7 \mathrm{~h}$. To exclude false positive and/or false negative results in the PCR analysis several controls have to be included into the methodology (Fig. 7). To exclude false negative results, the absence of inhibitors has to be shown by a control PCR using an internal standard or by spiking the DNA preparation with the target sequence. It is also possible to check DNA quality by a separate PCR using a target sequence always present in the product to be analyzed. For plant-based materials conserved regions of the $18 \mathrm{~S}$ ribosomal RNA gene could be chosen as primer binding sites. Since such a primer pair generates a PCR product with plant as well as fungal DNA, a missing 


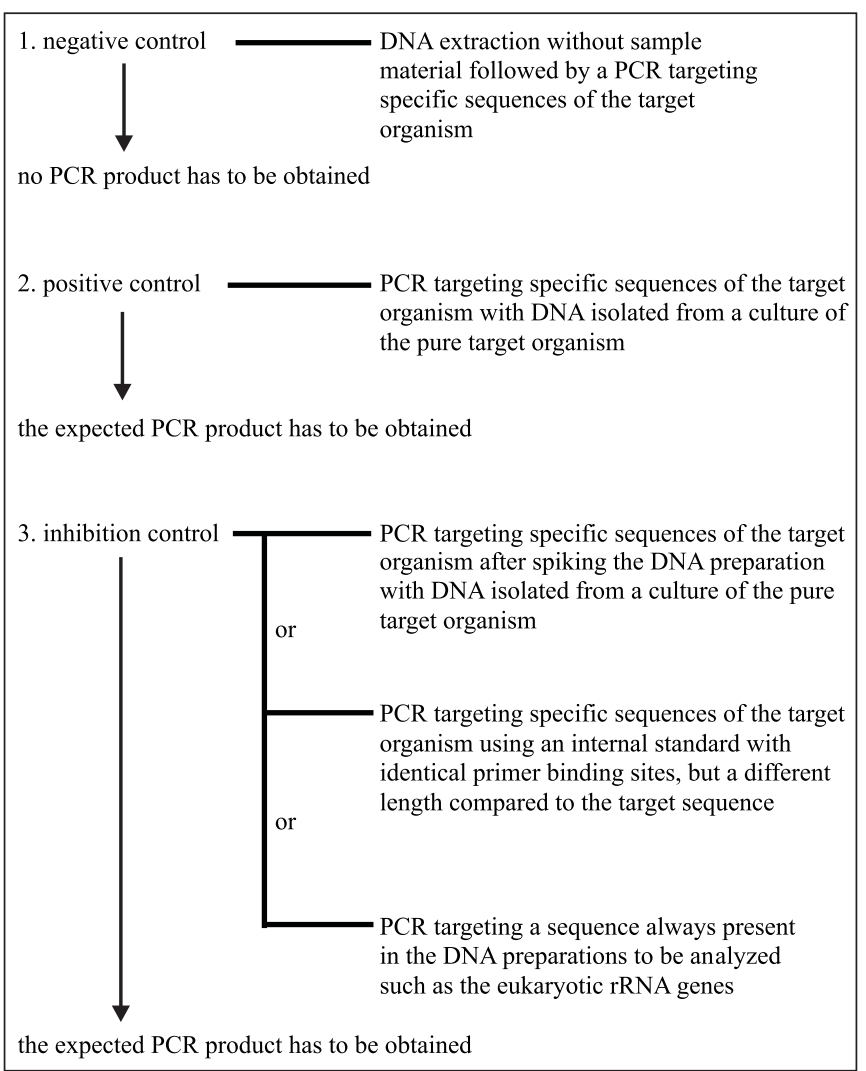

Figure 7. Control reaction which have to be included into a PCR assay to detect mycotoxigenic fungi.

amplification product in the above mentioned control reaction points either to PCR inhibitors or poor DNA quantity in the DNA preparations. False negative results might also be due to the inactivation of PCR reagents. To assure the quality of the PCR reagents, a positive control is used, that is the quality of the PCR reagents is tested by performing a PCR close to the limit of detection with pure target DNA. To avoid misinterpretation due to false positive results because of a contamination of reagents or the laboratory itself, a negative control is applied, that is performing the complete PCR assay from extraction to amplification without a DNA source.

\section{DETECTION OF PCR PRODUCTS}

One of the most frequently used methods for the detection of PCR products is agarose gel electrophoresis followed by staining with fluorescent dyes such as ethidium bromide or $\mathrm{SYBR}^{\circledR}$ Green, which fluoresce upon intercalation into the DNA double strand. A potentially mycotoxigenic fungi is supposed to be detected, if an amplification product of the predicted size is obtained. A verification of the PCR result is highly recommended, because sometimes false positive results have been observed, that is an amplification product not derived from the target sequence but, because of a very similar fragment length not distinguishable from the expected amplification product by agarose gel electrophoresis. To verify the PCR results, restriction analysis, that is specific cleavage of the amplification product by restriction endonucleases, or Southern blotting followed by hybridization, that is transfer of the amplification product onto a membrane followed by hybridization with a DNA probe specific for the target sequence, may be used. Alternatively amplification products may be verified by direct sequencing or a second nested or semi-nested PCR.

Appropriate technical equipment is recommended for detection of PCR products by agarose gel electrophoreses followed by staining with DNA dyes and the work is laborintensive and time-consuming. Furthermore, DNA dyes are hazardous for humans as they are potential mutagens. Therefore, novel system for a more rapid and convenient detection of PCR products have been developed $(26,36,41)$. One of the systems is based on a PCR in which one of the primers is biotinylated and digoxigenin-11-dUTP is incorporated during elongation (41). Biotinylated PCR products are captured on streptavidin-coated solid supports, and alkaline phosphatase conjugated to anti-digoxigenin antibody is subsequently bound to the incorporated digoxigenin. The detection may be obtained with colorimetric, fluorescent, or luminescent substrates for alkaline phosphatase. The detection system can be performed in microtiter plates allowing easy handling of multiple samples. The total assay time following the PCR is about $1 \mathrm{~h}$ dependent on the type of substrate and the type of solid support applied in the system.

Knoll et al. (26) adopted a new commercially available test strip system to set up a fast, sensitive and easy to handle method for the detection of Fusarium graminearum contamination in cereal samples. DNA Detection Test Strips ${ }^{\mathrm{TM}}$ were used for PCR product detection and the method was compared to agarose gel electrophoresis. Detection of PCR products was performed in only 20 min without the need of special technical equipment or hazardous fluorescent DNA dyes. A 5'-digoxigenin labeled primer pair targeting the galactose oxidase was used for PCR (Table 2). Hybridization of the PCR product was performed with a biotin labeled oligonucleotide probe specific for the DNA sequence of the PCR product. As an advantage over detection of a PCR fragment in agarose gels, the Test Strips ${ }^{\mathrm{TM}}$ provide both detection and identification. Even in the case of non-specific amplification, products which do not hybridize to the specific probe will not be detected, but in contrast to an agarose gel, the size of the PCR product can not be determined. Therefore, the use of DNA Detection Test Strips ${ }^{\mathrm{TM}}$ is only recommended if a completely optimized PCR protocol exists, in which it was already shown that the desired PCR product is generated, if target DNA is present in sufficient amounts. The limit of detection was found to be 260 pg template DNA per reaction with the Test Strip ${ }^{\mathrm{TM}}$ system. This is slightly higher in comparison to the use of gel 
electrophoresis for amplification product detection. In the agarose gel, a clearly visible signal could still be seen at a concentration of $65 \mathrm{pg}$ template DNA and at a concentration of $16.3 \mathrm{pg}$ DNA a faint band was still detectable.

Mishra et al. (36) developed a fluorescent-based PCR assay that allows a rapid and reliable identification of five toxigenic and pathogenic Fusarium species without the need of using hazardous fluorescent DNA dyes such as ethidium bromide. The species include Fusarium avenaceum, Fusarium culmorum, Fusarium equiseti, Fusarium oxysporum and Fusarium sambucinum (Table 2). The method is based on the PCR amplification of species-specific DNA fragments using fluorescent oligonucleotide primers, which were designed based on sequence divergence within the internal transcribed spacer region of nuclear ribosomal DNA. All the upstream primers were conjugated at their proximal end with different fluorescent dyes. The fluorophores were chosen so as to have minimal spectral overlap and can be excited with ultraviolet light. The five Fusarium species could be differentiated from each other on the basis of a single PCR amplification with high confidence and precision. Species-specific fluorescent PCR primers amplified an expected size DNA fragment only from the isolates of Fusarium species from which the primer was originally designed. The resulting color was clearly visible after exciting the electrophoresed agarose gel with ultraviolet light. The technique was further modified to preclude the need for gel electrophoresis. The PCR products were purified using Qiagen PCR Purification Kit to remove excess, unused and non-conjugated dye, and unused primers. Subsequently, the amplified color was visualized under ultraviolet light in reaction tubes, which were photographed with a hand-held Polaroid camera.

\section{RNA-BASED APPROACH}

It has to be kept in mind that the absence of a PCR band does not necessarily imply that the analyzed strain is unable to produce mycotoxins. For example, a mutation in the primer binding site not affecting the functionality of the encoded protein could be the reason for a missing PCR product. In addition, the generation of the expected PCR product does not necessarily imply that the analyzed strain is capable of producing mycotoxins, because the presence of a PCR product does not allow to draw any conclusion about expression of the respective gene. However, the presence or lack of mRNAs may permit direct differentiation between mycotoxin-producing and nonproducing strains. Although Northern hybridization analysis and RNAse protection assays are well established and reliable techniques for the detection of mRNAs, their sensitivity may be insufficient for the detection of low levels of gene transcription. Therefore, detection systems based on reverse transcription PCR (RT-PCR) have been developed to monitor aflatoxin production in Aspergillus parasiticus (50) and trichothecene production in Fusarium culmorum (14). RT-PCR has been demonstrated to be 100-1000 times more sensitive than Northern hybridization analysis. In addition, several specific mRNAs may be detected simultaneously in a single RNA sample by multiplex RT-PCR. RT-PCR allows the detection of mRNAs transcribed by specific genes by the PCR amplification of cDNA intermediates synthesized by reverse transcription. Sweeney et al. (50) designed two pairs of oligonucleotide primers from the coding regions of the structural gene ord 1 , which encodes a cytochrome $\mathrm{P} 450$ monooxygenase involved in the conversion of the penultimate aflatoxin pathway intermediate $\mathrm{O}$ methylsterigmatocystin to aflatoxin B1, and the intronless regulatory gene aflR that positively regulates the transcription of the aflatoxin biosynthetic genes (Fig. 4, Table 3). Total RNA was used as a template to synthesize cDNAs with random hexamer primers and reverse transcriptase. The resulting cDNA was amplified by PCR using the specific primers. Since genomic DNA sequences homologous to RNA targets present in the PCR reaction may interfere with the detection of RNA by RTPCR, the RNA preparations were treated with DNAse I first. As a control, the gene transcription of a housekeeping gene, $B$ tubulin, was monitored by RT-PCR. To distinguish cDNA from genomic DNA targets, the ord 1 and $\beta$-tubulin primers were designed from coding regions flanking introns, so that the decreased size of the RT-PCR product relative to the PCR product derived from genomic DNA could be discerned. This strategy allows the detection of false positive reactions resulting from contamination of the RNA treated with DNase I with genomic DNA from foreign cellular material or carry-over contamination from previous PCR reactions and also assessed the efficiency of the DNase I treatment of the isolated RNA. The developed RT-PCR was successfully used to distinguish aflatoxin-producing from non-producing Aspergillus parasiticus strains, but this technique has also the potential to be employed as a tool to investigate the effects of a variety of physiological factors on the transcription of the aflatoxin genes. In addition, the RT-PCR primers designed from aflatoxin genes of Aspergillus parasiticus may also be employed to monitor the transcription of aflatoxin genes of Aspergillus flavus as aflatoxin gene homology is very high between these two aflatoxigenic species.

Doohan et al. (14) developed a RT-PCR assay to successfully study the expression of the tri5 gene involved in trichothecene biosynthesis in Fusarium species (Fig. 6, Table 3). Quantification of tri5 gene expression was performed relative to expression of B-tubulin, which has been used previously as a measure of mRNA extraction efficiency and fungal biomass. The $\beta$-tubulin and tri5 primer sets both flanked introns within the respective genes, which allowed size differentiation of amplified genomic DNA and mRNA. Quantification of B-tubulin expression in RNA extracts obtained in a time course experiment in which genomic DNA was used as a competitor template showed, that 
ß-tubulin expression was constant over time. $\beta$-Tubulin was used to normalize the tri5 expression results and thus accounted for any variability arising from the RNA quantification or RT step. Tri5 expression at 24, 48, 72 and $96 \mathrm{~h}$ post-inoculation was quantified relative to expression of B-tubulin, and the DON contents of culture supernatants were determined. Under these conditions, a direct relationship between tri5 expression and the increase in DON production over time was observed.

\section{QUANTITATIVE PCR}

Compared to DNA, however, RNA is relatively unstable. This is largely due to the presence of ribonucleases (RNases), which break down RNA molecules. RNases are very stable, do not require cofactors, are effective in very small quantities, and are difficult to inactivate. Isolation and analysis of RNA therefore requires specialized techniques. This situation is even more complicated by the fact that changes in gene expression can occur during handling of the sample and isolation of the RNA. To avoid the need of RNA isolation, it was investigated, if the amount of PCR product generated from a DNA target correlates with fungal biomass or even mycotoxin concentration of a given sample. Niessen and Vogel (42) used the Tox5 PCR assay (Table 3) to analyze samples of wheat for the presence of trichothecene-producing Fusarium species and they found that the intensities of the PCR bands were well correlated with the concentration of DON detected by HPLC in the same wheat samples. This implies that there is a quantitative correlation between toxin production and biomass in naturally contaminated materials, which was denied by most studies performed in the past. Since different numbers of target molecules in the samples used for PCR may result in identical numbers of the amplification product in the plateau phase and identical numbers of target molecules in different numbers of the amplification product, it is, in general, not possible to conclude from the numbers of the PCR product generated in a standard PCR to the numbers of target molecules originally present in the samples used for PCR. Therefore, quantitative PCR systems have been developed which do not use end point measurement to quantify the amount of target molecules present in the sample, such as the real time PCR systems, or in which such a end point measurement does not pose problems for quantification, such as competitive PCR.

\section{COMPETITIVE PCR}

The principle of the competitive PCR is a co-amplification of an increasing amount of target DNA with a defined amount of a competitor, that is an internal DNA standard. Therefore tubeto-tube differences and inhibitors do not interfere, because their effect on target and competitor is identical. To guarantee nearly identical amplification efficiencies of both the target and the competitor sequence, the same primer binding sites are used to amplify the target DNA and the competitor. Both amplification products should be distinguished from each other by a difference in fragment length. Therefore, the competitor is constructed by introduction of short deletions or insertions into the target sequence. Some studies have indicated that the use of homologous competitors may lead to heterodimer formation during PCR. For this reason, heterologous competitors were generated, which had $5^{\prime}$ and $3^{\prime}$ termini identical to the fungal target primer binding sites, but which had no internal sequence homology to the target sequence. This approach, however, may result in different amplification efficiencies of the target and competitor sequences. Since the competitor is used as an internal DNA standard it acts also as an internal amplification control. For quantification, a calibration curve with a serially diluted solution of pure fungal genomic DNA has to be generated with every experiment. In general, a log-log plot of PCR product ratio against fungal DNA concentration gives a linear regression. PCR product ratios were determined after densitometric gel evaluation by dividing the band intensity of the target DNA product by that of the competitor product. Nicholson et al. (40) developed a competitive PCR assay based on RAPD primers to detect and quantify Fusarium culmorum and Fusarium graminearum in cereals (Table 2). Competitive PCR indicated that the barley and wheat samples studied are contaminated with different levels of Fusarium culmorum or Fusarium graminearum, respectively, but no approach was made to correlate this amount of fungal DNA with pathogen biomass.

A PCR-based assay to quantify trichothecene-producing Fusarium based on primers derived from the trichodiene synthase encoding gene tri5 was developed by Edwards et al. (15) (Table 3). Regression analysis of trichothecene-producing Fusarium and DON in harvested grain from an inoculated-field trial showed a good correlation between tri5 DNA and the amount of DON produced. This relationship will probably be weaker for field samples, which may differ in the trichotheceneproducing isolates present. Those isolates may differ in their capability to produce DON or, in the case of Fusarium graminearum, in the relative amounts of DON and NIV that they produce.

\section{REAL TIME PCR}

Competitive PCR needs little capital investment and little expenditure on consumables, but, on the other hand, competitive PCR is time-consuming and labor-intensive. In contrast, real time PCR systems are more convenient and more rapid, but expensive thermocyclers equipped with a fluorescence reader are needed. Real time PCR enables calculation of the amount of PCR product present in a sample at a point of the reaction in which strict exponentiality of DNA amplification is given. The so called LightCycler ${ }^{\mathrm{TM}}$ - and TaqMan ${ }^{\mathrm{TM}}$-technology are mainly 
used in the detection and quantification of mycotoxigenic fungi. Both methods are well suited for automation and high throughput of samples.

\section{LIGHTCYCLER ${ }^{\mathrm{TM}}$ PCR}

The LightCycler ${ }^{\mathrm{TM}}$-system makes use of performing PCR in a small reaction volume in a glass capillary exposed to a temperature regulated air stream, which results in very rapid thermal cycling protocols. A PCR with 35 cycles is completed within about $25 \mathrm{~min}$, but due to the LightCycler ${ }^{\mathrm{TM}}$ only 32 samples can be run at the same time. For quantitative PCR, a fluorescence technique based on $S Y B R^{\circledR}$ Green dye was applied. The dye possesses selective affinity to double stranded DNA and the binding greatly enhances fluorescence emission of the molecule at $530 \mathrm{~nm}$. SYBR ${ }^{\circledR}$ Green does not react with single stranded DNA or with RNA present in the sample. Intensity of fluorescence at $530 \mathrm{~nm}$ is proportional to the concentration of double stranded DNA and thus providing a measure for the quantity of newly synthesized product during PCR. For quantification, a calibration curve with a serially diluted solution of pure fungal genomic DNA has to be generated with each setup of the real time PCR. A drawback of this method might be the unspecific binding of SYBR ${ }^{\circledR}$ Green to double stranded DNA in which case false positive reactions may result. Therefore, amplification products are characterized by melting point analysis. Non-specific products should be distinguished from the desired PCR product by a difference in the melting points.

Bagnara et al. (4) developed a SYBR ${ }^{\circledR}$ Green quantitative PCR system based on the nor 1 gene to detect and quantify aflatoxigenic Aspergillus flavus in black pepper (Table 3). The minimal cell number which can be detected by this system was determined to be $4.5 \times 10^{3} / \mathrm{g}$ of pepper. Non-infected pepper gave always negative results both with the PCR approach as well as with plate counting. With infected pepper, the initial nor 1 copy numbers were always higher than the spore numbers obtained by plate counting and it was not possible to correlate the nor 1 copy numbers with the spore numbers. In general both values increased with prolonged incubation time, but the ratio of the nor 1 copy numbers to the spore numbers decreased steadily from about $5 \times 10^{3}$ after 5 days of incubation to only about 15 after 15 days of incubation.

A SYBR ${ }^{\circledR}$ Green quantitative PCR system based on the tri5 gene to detect and quantify trichothecene-producing Fusarium species in cereal samples was developed by Schnerr et al. (45) (Table 3). The detection limit of the PCR system was determined to be below $50 \mathrm{pg}$ of fungal DNA. The developed LightCycler ${ }^{\mathrm{TM}}$ PCR assay provided a highly reproducible measurement, since an average coefficient of variation of $2 \%$ over the whole concentration range, with the highest variation at the lower concentrations, was found. The sensitivity of the PCR was greatly improved by Hot Start technique and the use of 1 unit of pyrophosphatase per amplification reaction resulted in a $10 \%$ improvement in PCR product yield. The application of uracil DNA glycosylase prevented carry-over of contaminating PCR products. Uracil DNA glycosylase has no effect on native DNA, because native DNA does not contain uracil and in addition, the enzyme is inactivated by heat denaturation prior to PCR, in which deoxythymidin triphosphate (dTTP) has to be substituted by deoxyuracil triphosphate (dUTP). The developed quantitative LightCycler ${ }^{\mathrm{TM}}$ PCR-based assay was used to quantify the DNA from trichothecene-producing Fusarium species in 300 field inoculated wheat samples (46). The minimum detectable quantity of template DNA was $16 \mathrm{ng}$ per gram of sample corresponding to 290 gene copies. Data analysis revealed a positive, linear correlation with a coefficient of correlation of $\mathrm{r}=0.9557$ between DON concentration and DNA amounts over all samples. This correlation was demonstrated to be highly significant. If only the samples with DON concentrations below $1.5 \mathrm{mg} / \mathrm{kg}$ were analyzed, a correlation $\mathrm{r}=0.7476$ between DON concentration and DNA amounts were calculated. An interval of confidence for $\mathrm{P}=95 \%$ was calculated based on samples with DON concentrations below $1.5 \mathrm{mg} / \mathrm{kg}$. Only 12 of 234 samples had data points which were outside the calculated interval. As an example, the range of probable DON concentration at a given DNA content of $0.5 \mathrm{mg} / \mathrm{kg}$ was calculated to be $0.74 \pm 0.57 \mathrm{mg} /$ $\mathrm{kg}$. This means, a sample with this concentration of Fusarium DNA will display a DON concentration between 0.17 and 1.31 $\mathrm{mg} / \mathrm{kg}$ with a probability of $95 \%$. Divergence from such a correlation may be explained by the fact that the PCR measures the total Fusarium biomass in the samples, whereas the microbiological technique applied measures the percentage of kernels infected, rather than biomass. In addition, only living mycelia is detected by plate counting. Therefore, the developed LightCycler ${ }^{\mathrm{TM}}$ PCR is a suitable tool, because it provides a measure for the determination of biomass changes over time, taking in account living mycelia actively producing DON but also dead mycelia, which formerly had contributed to the DON content actually found.

\section{TAQMAN ${ }^{\mathrm{TM}}$ PCR}

The TaqMan ${ }^{\mathrm{TM}}$-technology makes use of the $5^{\prime}-3^{\prime}$ exonuclease activity of the polymerase to generate a templatespecific fluorescent signal after hydrolyzing an internal probe during each step of the PCR. The internal probe is $5^{\prime}$-labeled with a reporter fluorescent dye and 3'-ligated to a quencher dye. As long as the reporter fluorescent dye and the quencher dye are located in close proximity on the internal probe, the quencher dye greatly reduces the fluorescence emitted by the reporter dye by Förster energy resonance transfer (FRET) through space. During PCR, the reporter dye is separated from the quencher dye, which results in an increase of the reporter dye signal. Only if the internal probe is binding to the DNA in 
between the two PCR primers a fluorescence signal during PCR is generated. Therefore, this additional hybridization step increases the specificity of the PCR. False negative results due to PCR inhibitors could be excluded by using an internal amplification control in each PCR. The parameter measured is the threshold-cycle (CT) where each reaction trespasses a certain fluorescence level. In comparison to the LightCycler ${ }^{\mathrm{TM}}$ PCR, the TaqMan ${ }^{\mathrm{TM}}$ PCR needs more time, but on the other hand, more samples can be run at the same time. APCR with 45 cycles is completed within about $2 \mathrm{~h}$ with at maximum 96 single reactions per run. For quantification, a calibration curve with a serially diluted solution of pure fungal genomic DNA has to be generated with each set-up of the real time PCR.

A TaqMan ${ }^{\mathrm{TM}}$ quantitative PCR system directed against the nor 1 gene of the aflatoxin biosynthetic pathway as a target sequence has been developed by Mayer et al. (30) (Table 3). The PCR was applied to detect an aflatoxigenic Aspergillus flavus strain in artificially contaminated plant-type foods like maize, pepper and paprika. In general, a good correlation between the spore numbers, determined by microscopic counting, and the nor 1 gene numbers was observed, however, compared to the spore numbers, the nor 1 copy numbers were always higher. The detection limit of this PCR system was determined to be about $10^{3}$ cells per gram for the pepper and somewhat higher for the maize and paprika samples. It was suggested that with low fungal DNA concentrations an inhibition takes place, apparently by competition through high amounts of unspecific plant DNA. The general observation that the target gene copy numbers determined by quantitative real time PCR are higher than the spore numbers determined by plate counting might be due to the recording of viable and dead cells by PCR, but not by plate counting as well as the presence of mycelial fragments in the samples to be analyzed. Mycelial fragments will give rise to only one colony, even if they consist of many cells. In addition, mycelial cells carry several nuclei and each nucleus contributes to the number of target gene copies. The target gene copy numbers were reported to be 1.2 to $3.5 \log$ units higher than the spore numbers.

\section{CONCLUSIONS AND FUTURE PERSPECTIVES}

PCR may be applied to the screening of agricultural commodities for the absence of mycotoxin producers prior to or even after processing. Negative results in this assay indicate that a sample should be virtually free of mycotoxins. Since the presence of a mycotoxigenic fungus is no assurance that it was producing the mycotoxin, the positive samples left must be analyzed for the presence of mycotoxins using physico-chemical standard methods. Considering consumer protection, false positive results in the PCR are of no concern, but from an economic point of view the number of false positive results should be as low as possible. The usefulness of the PCR methods developed so far to monitor quality and safety in the food an feed industry was already demonstrated. It seems to be even possible by using a quantitative approach to correlate the number of target molecules with fungal biomass or even mycotoxin content. The real time PCR systems have furthermore the potential to be adapted to quantify mRNA, which can be used for monitoring the expression of genes involved in mycotoxin biosynthesis under particular environmental conditions in different foods. Preliminary results on this field are very encouraging.

The most promising breakthroughs in the detection of mycotoxins or mycotoxigenic fungi are expected to be made in the area of sensor technology. Bio-sensors can be used for the detection of very different analytes such as pathogens, pesticides and toxins. They are a subgroup of chemical sensors where the analytical devices are composed of a biological recognition element such as enzymes, antibodies, receptors, proteins, oligonucleotides, or even a whole cell coupled to a chemical or physical transducer, which measures the changes that occur when the sensor couples to its analyte. Only a limited amount of methods are combined and currently exploited for their use in food control. As recognition elements, bioaffinity based receptors that use the selective interaction between ligand and receptor, antibody or nucleic acid are most widely used. As transducers, electrochemical and optical systems have gained practical importance. Microarrays are constructed of a high number of parallel hybrid receptors. They are often referred to as biochips and allow to conduct many analyses in parallel. The advantages over conventional methods of bioanalysis include that a variety of analytes are detected simultaneously in the same sample, that the required sample quantities are minimal and that a high sample throughput is possible. Applications of biochips with low-density arrays, that are arrays with a few hundred different dots, take place in a variety of bioanalytical fields. The systems have high potential for automation and allow the construction of simple and portable equipment for fast analysis.

For the detection of mycotoxins microarrays are under development in which specific antibodies are immobilized on the sensor surface. It is planned to detect at least nine different mycotoxins in parallel (3). Another assay is designed as an inhibition assay (52), in which a fixed concentration of mycotoxin specific antibody is mixed with a sample containing an unknown amount of mycotoxin, whereby antibody and mycotoxin form a complex. The sample is then passed over a sensor surface to which mycotoxin has been immobilized. Non-complexed antibodies are measured as they bind to the mycotoxin on the sensor surface. Mycotoxigenic fungi could also be detected using a microarray with immobilized oligonucleotides, which capture specifically the amplification products generated in a separate mycotoxigenic fungi-specific multiplex PCR or even in an on-chip PCR. 


\section{REFERENCES}

1. Anonymous. Nachweis von Campylobacter jejuni und Campylobacter coli in Lebensmitteln durch Amplifizierung spezifischer Gensequenzen mit der Polymerase-Kettenreaktion. Bundesgesundheitsbl., 43:816824,2000

2. Anonymous. Nachweis von Listeria monocytogenes in Lebensmitteln mit der Polymerase-Kettenreaktion (PCR). Bundesgesundheitsbl., 45:59-66, 2002.

3. Anonymous, www.biohytec.de

4. Bagnara, A.; Mayer, Z.; Geisen, R. Quantification of Aspergillus flavus BFE96 by SYBR green Q-PCR in black pepper. Mycotox. Res., 16:244-247, 2000.

5. Bakan, B.; Giraud-Delville, C.; Pinson, L.; Richard-Molard, D.; Fournier, E.; Brygoo, Y. Identification by PCR of Fusarium culmorum strains producing large and small amounts of deoxynivalenol. Appl. Environm. Microbiol., 68:5472-5479, 2002.

6. Bluhm, B.H.; Flaherty, J.E.; Cousin, M.A.; Woloshuk, C.P. Multiplex polymerase chain reaction assay for the differential detection of trichothecene- and fumonisin-producing species of Fusarium in cornmeal. J. Food Protect., 65:1955-1961, 2002.

7. Candrian, U. Die Polymerase-Kettenreaktion in der Lebensmittelanalytik. Mitt. Gebiete Lebensm. Hyg., 85:704-718, 1994

8. Chen, R.-S.; Tsay, J.-G.; Huang, Y.-F.; Chiou, R.Y.-Y. Polymerase chain reaction-mediated characterization of molds belonging to the Aspergillus flavus group and detection of Aspergillus parasiticus in peanut kernels by a multiplex polymerase chain reaction. J. Food Protect., 65:840-844, 2002.

9. Criseo, G.; Bagnara, A.; Bisignano, G. Differentiation of aflatoxinproducing and non-producing strains of Aspergillus flavus group. Lett. Appl. Microbiol., 33:291-295, 2001.

10. Cruickshank, R.H.; Pitt, J.I. Identification of species in Penicillium subgenus Penicillium by enzyme electrophoresis. Mycologia, 79:614620, 1987

11. Dall’Asta, C.; Galaverna, G.; Sforza, S.; Biancardi, A.; Dossena, A.; Marchelli, R. New HPLC-FLD and HPLC-ESI-MS methods for the simultaneous detection of type A and type B trichothecenes. In: Eklund, T.; De Brabander, H.; Daeseleire, E.; Dirinck, I.; Ooghe, W. (Eds.). Strategies for safe food. Analytical, industrial and legal aspects: Challenges in organisation and communication. Euro Food Chem XII. Proceedings Vol. 2, Koninklijke Vlaamse Chemische Vereniging, Heverlee, 2003, p.608-612.

12. Demyttenaere, J.C.; Morina, R.M.; Sandra, P. Monitoring and fast detection of mycotoxin-producing fungi based on headspace solidphase microextraction and headspace sorptive extraction of the volatile metabolites. J. Chromatogr. A, 985:127-135, 2003.

13. Dickinson, J.H.; Kroll, R.G.; Grant, K.A. The direct application of the Polymerase Chain Reaction to DNA extracted from foods. Lett. Appl. Microbiol., 20:212-216, 1995.

14. Doohan, F.M.; Weston, G.; Rezanoor, H.N.; Parry, D.W.; Nicholson, P. Development and use of a reverse transcription-PCR assay to study expression of Tri5 by Fusarium species in vitro and in planta. Appl. Environm. Microbiol., 65:3850-3854, 1999.

15. Edwards, S.G.; Pirgozliev, S.R.; Hare, M.C.; Jenkinson, P. Quantification of trichothecene-producing Fusarium species in harvested grain by competitive PCR to determine efficacies of fungicides against Fusarium head blight of winter wheat. Appl. Environm. Microbiol., 67:1575-1580, 2001.

16. Färber, P.; Geisen, R.; Holzapfel, W.H. Detection of aflatoxigenic fungi in figs by a PCR reaction. Int. J. Food Microbiol., 36:215-220, 1997.

17. Gachet, E.; Martin, G.G.; Vingeneau, F.; Meyer, G. Detection of genetically modified organisms by PCR: a brief review of methodologies available. Trends in Food Science \& Technologie, 9:380-388, 1999 .
18. Geisen, R. Multiplex polymerase chain reaction for the detection of potential aflatoxin and sterigmatocystin producing fungi. System. Appl. Microbiol., 19:388-392, 1996.

19. Geisen, R. PCR methods for the detection of mycotoxin-producing fungi. In: Bridge, P.D.; Arora, D.K.; Reddy, C.A.; Elander, R.P. (eds). Application of PCR in mycology. CAB International, New York, 1998, p.243-266.

20. Geisen, R.; Mulfinger, S.; Niessen, L. Detection of Aspergillus flavus in wheat by PCR. J. Food Mycol., 1:211-218, 1998.

21. Greiner, R.; Jany, K.D. Use of polymerase chain reaction (PCR) in food control: Detection of genetically modified food and food-borne pathogens. Pol. J. Food Nutr. Sci., 11:112-118, 2002.

22. Greiner, R.; Konietzny, U.; Jany, K.D. Is there any possibility of detecting the use of genetic engineering in processed foods ? Z Ernährungswiss., 36:155-160, 1997.

23. Grimm, C.; Geisen, R. A PCR-ELISA for the detection of potential fumonisin producing Fusarium species. Lett. Appl. Microbiol., 25:456-462, 1998.

24. Hoef, A.M.; Kok, E.J.; Bouw, E.; Kuiper, H.A.; Keijer, J. Development and application of a selective detection method for genetically modified soy and soy-derived products. Food. Addit. Contam., 15:767-774, 1998.

25. Hupfer, C.; Hotzel, H.; Sachse, K.; Engel, K.-H. Detection of the genetic modification in heat-treated products of Bt maize by polymerase chain reaction. Z. Lebensm. Unters. Forsch., 206:203207, 1998.

26. Knoll, S.; Vogel, R.F.; Niessen, L. Identification of Fusarium graminearum in cereal samples by DNA Detection Test Strips ${ }^{\mathrm{TM}}$. Lett. Appl. Microbiol., 34:144-148, 2002.

27. Kwaga, J.; Iverson, J.O.; Misra, V. Detection of pathogenic Yersinia enterocolitica by polymerase chain reaction and digoxigenin-labelled polynucleotide probes. J. Clin. Microbiol., 30:2668-2673, 1992.

28. Lee, T.; Oh, D.-W.; Kim, H.-S.; Lee, J.; Kim, Y.-H.; Yun, S.-H.; Lee, Y.-W. Identification of deoxynivalenol- and nivalenol-producing chemotypes of Gibberella zeae by using PCR. Appl. Environm. Microbiol., 67:2966-2972, 2001.

29. Liewen, M.B.; Bullerman, L.B. Toxigenic fungi and fungal toxins In: Vanderzant, C.; Splittstoesser, D.F. (Eds). Compendium of methods for the microbiological examination of foods. $3^{\text {rd }}$ ed., American Public Health Association, Washington DC, 1999, p.811-819.

30. Mayer, Z.; Bagnara, A.; Färber, P.; Geisen, R. Quantification of the copy number of nor-1, a gene of the aflatoxin biosynthetic pathway by real-time PCR, and its correlation to the cfu of Aspergillus flavus in foods. Int. J. Microbiol., 82:143-151, 2003.

31. Meyer, R. Development and application of DNA analytical methods for the detection of GMOs in foods. Food control, 10:391-399, 1999.

32. Meyer, R.; Candrian, U. PCR-based DNA analysis for the identification and characterization of food components. Lebensm. Wiss. u. Technol., 29:102-111, 1996.

33. Meyer, R.; Candrian, U.; Lüthy, J. Tierartenbestimmung und Sojanachweis in erhitzten Fleischprodukten mittels PolymeraseKettenreaktion (PCR). Mitt. Gebiete Lebensm. Hyg., 84:112-121, 1993.

34. Meyer, R.; Candrian, U.; Lüthy, J. Detection of pork in heated meat products by the polymerase chain reaction. J. Assoc. Off. Anal. Chem., 77:617-622, 1994.

35. Meyer, R.; Chardonnens, F.; Hübner, P.; Lüthy, J. Polymerase Chain Reaction (PCR) in the quality and safety assurance of food: Detection of soya in processed meat products. Z. Lebensm. Unters. Forsch., 203:339-344, 1996.

36. Mishra P.K.; Fox, R.T.V.; Culham, A. Development of a PCR-based assay for rapid and reliable identification of pathogenic Fusaria. FEMS Microbiol. Lett., 218:329-332, 2003.

37. Möller, E.M.; Chelkowski, J.; Geiger, H.H. Species-specific PCR assays for the fungal pathogens Fusarium moniliforme and Fusarium 
subglutinans and their application to diagnose maize ear rot disease. J. Physiopath., 147:497-508, 1999.

38. Mulfinger, S.; Niessen, L.; Vogel, R.F. PCR based quality control of toxigenic Fusarium spp. in brewing malt using ultrasonic for rapid sample preparation. Adv. Food Sci., 22:38-46, 2000.

39. Murillo, E.; Cavallarin, L.; San Segudo, B. The development of a rapid PCR assay for detection of Fusarium moniliforme. Eur. J. Plant Pathol., 104:301-311, 1998.

40. Nicholson, P.; Simpson, D.R.; Weston, G.; Rezanoor, H.N.; Lees, A.K.; Parry, D.W.; Joyce, D. Detection and quantification of Fusarium culmorum and Fusarium graminearum in cereals using PCR assays. Physiol. Mol. Plant. Pathol., 53:17-37, 1998.

41. Niessen, L.; Klusmann, J.; Vogel, R.F. Quantitative estimation of Fusarium graminearum DNA using a solid phase PCR assay (DIAPOPS). J. Food Mycol., 1:73-84, 1998.

42. Niessen, L.; Vogel, R.F. Group specific PCR-detection of potential trichothecene-producing Fusarium-species in pure cultures and cereal samples. System. Appl. Microbiol., 21:618-631, 1998.

43. Paterson, R.R.M.; Archer, S.; Kozakiewicz, Z.; Lea, A.; Locke, T.; O'Grady, E. A gene probe for the patulin metabolic pathway with potential for use in patulin and novel disease control. Biocontrol Sci. Technol., 10:509-512, 2000.

44. Rossen, L.; Nørskov, P.; Holmstrøm, K.; Rasmussen, O.F. Inhibition of PCR by components of food samples, microbial diagnostic assays and DNA-extraction solutions. Int. J. Food Microbiol., 17:37-45, 1992.

45. Schnerr, H.; Niessen, L.; Vogel, R.F. Real time detection of the tri5 gene in Fusarium species by LightCycler ${ }^{\mathrm{TM}}$-PCR using SYBR ${ }^{\circledR}$ Green I for continuous fluorescence monitoring. Int. J. Microbiol., 71:53-61, 2001.

46. Schnerr, H.; Vogel, R.F.; Niessen, L. Correlation between DNA of trichothecene-producing Fusarium species and deoxynivalenol concentrations in wheat-samples. Lett. Appl. Microbiol., 35:121$125,2002$.

47. Shapira, R.; Paster, N.; Eyal, O.; Menasherov, M.; Mett, A.; Salomon, R. Detection of aflatoxigenic molds in grains by PCR. Appl. Environm. Microbiol., 62:3270-3273 (1996).

48. Smith, J.E.; Lewis, C.W.; Anderson, J.G.; Solomons, G.L. Mycotoxins in human nutrition and health. European Commission, Brussels, 1994, 300p.
49. Sweeney, M.J.; Dobson, A.D.W. Mycotoxin production by Aspergillus, Fusarium and Penicillium species. Int. J. Food Microbiol., 43:141-158, 1998.

50. Sweeney, M.J.; Pàmies, P.; Dobson, A.D.W. The use of reverse transcription-polymerase chain reaction (RT-PCR) for monitoring aflatoxin production in Aspergillus parasiticus 439. Int. J. Food Microbiol., 56:97-103, 2000.

51. Tsen, H.-Y.; Chi, W.-R.; Lin, C.-K. Use of novel polymerase chain reaction primers for the specific detection of heat-labile toxin I, heat-stable toxin I and II enterotoxigenic Escherichia coli in milk. J. Food Prot., 59:795-802, 1996.

52. van der Gaag, B.; Spath, S.; Dietrich, H.; Stigter, E.; Boonzaaijer, G.; van Osenbruggen, T.; Koopal, K. Biosensors and multiple mycotoxin analysis. Food Control, 14:251-254.

53. van Duijn, G.; van Biert, R.; Bleeker-Marcelis, H.; Peppelman, H.; Hessing, M. Detection methods for genetically modified crops. Food control, 10:375-378, 1999.

54. van Quekelberghe, S.; De Graeve, K.; Cordonnier, J. Simultaneous screening of 12 mycotoxins by Liquid Chromatography Tandem Mass Spectrometry. In: Eklund, T.; De Brabander, H.; Daeseleire, E.; Dirinck, I.; Ooghe, W. (Eds.). Strategies for safe food. Analytical, industrial and legal aspects: Challenges in organisation and communication. Euro Foof Chem XII. Proceedings Vol. 2, Koninklijke Vlaamse Chemische Vereniging, Heverlee, 2003, p.706709.

55. Villalobo E.; Torres A. PCR for detection of Shigella spp. in myonnaise. Appl. Environm. Microbiol., 64:1242-1245, 1998.

56. White, T.J.; Bruns, T.; Lee, S.; Taylor, J. Amplification and direct sequencing of fungal ribosomal RNA genes for phylogenetics. In: Innis, M.A.; Gelfland, D.H.; Sninsky, J.J.; White, T.J. (Eds.). PCR Protocols. Academic Press, San Diego, 1990, p.315-322.

57. Yong, R.K.; Cousin, M.A. Detection of moulds producing aflatoxins in maize and peanuts by an immunoassay. Int. J. Food Microbiol., 65:27-38, 2001.

58. Zimmermann, A.; Lüthy, J.; Pauli, U. Quantitative and qualitative evaluation of nine different extraction methods for nucleic acids on soybean food samples. Z. Lebensm. Unters. Forsch., 207:81-90, 1998. 